\title{
Review \\ Role of Epicardial Adipose Tissue in Cardiovascular Diseases: A Review
}

\author{
Michał Konwerski, Aleksandra Gąsecka (D), Grzegorz Opolski (D), Marcin Grabowski (1) and Tomasz Mazurek *(D)
}

check for updates

Citation: Konwerski, M.; Gąsecka, A.; Opolski, G.; Grabowski, M.; Mazurek, T. Role of Epicardial Adipose Tissue in Cardiovascular Diseases: A Review. Biology 2022, 11, 355. https://doi.org/10.3390/biology 11030355

Academic Editor: Lemin Zheng

Received: 13 January 2022

Accepted: 21 February 2022

Published: 23 February 2022

Publisher's Note: MDPI stays neutral with regard to jurisdictional claims in published maps and institutional affiliations.

Copyright: (C) 2022 by the authors. Licensee MDPI, Basel, Switzerland. This article is an open access article distributed under the terms and conditions of the Creative Commons Attribution (CC BY) license (https:// creativecommons.org/licenses/by/ $4.0 /)$.

\author{
1st Chair and Department of Cardiology, Medical University of Warsaw, 02-097 Warszawa, Poland; \\ konwerski.mich@gmail.com (M.K.); aleksandra.gasecka@wum.edu.pl (A.G.); \\ grzegorz.opolski@wum.edu.pl (G.O.); marcin.grabowski@wum.edu.pl (M.G.) \\ * Correspondence: tmazurek@kardia.edu.pl; Tel.: +48-(22)-5991958
}

Simple Summary: Cardiovascular diseases (CVDs) are the leading causes of death worldwide. Epicardial adipose tissue (EAT) is one of the most important risk factors for cardiovascular events and a promising new therapeutic target in CVDs. Here, we summarize the currently available evidence regarding the role of EAT in the development of CVDs, including coronary artery disease, heart failure and atrial fibrillation; compile data regarding the association between EAT's function and the course of COVID-19; and present new potential therapeutic possibilities, aiming at modifying EAT's function. The development of novel therapies specifically targeting EAT could revolutionize the prognosis in CVDs.

\begin{abstract}
Cardiovascular diseases (CVDs) are the leading causes of death worldwide. Epicardial adipose tissue (EAT) is defined as a fat depot localized between the myocardial surface and the visceral layer of the pericardium and is a type of visceral fat. EAT is one of the most important risk factors for atherosclerosis and cardiovascular events and a promising new therapeutic target in CVDs. In health conditions, EAT has a protective function, including protection against hypothermia or mechanical stress, providing myocardial energy supply from free fatty acid and release of adiponectin. In patients with obesity, metabolic syndrome, or diabetes mellitus, EAT becomes a deleterious tissue promoting the development of CVDs. Previously, we showed an adverse modulation of gene expression in pericoronary adipose tissue in patients with coronary artery disease (CAD). Here, we summarize the currently available evidence regarding the role of EAT in the development of CVDs, including CAD, heart failure, and atrial fibrillation. Due to the rapid development of the COVID-19 pandemic, we also discuss data regarding the association between EAT and the course of COVID-19. Finally, we present the potential therapeutic possibilities aiming at modifying EAT's function. The development of novel therapies specifically targeting EAT could revolutionize the prognosis in CVDs.
\end{abstract}

Keywords: atherosclerosis; cardiovascular diseases; epicardial adipose tissue; EAT; inflammation

\section{Introduction}

Cardiovascular diseases (CVDs) remain one of the leading causes of death worldwide [1,2], entailing enormous costs for healthcare systems [3]. Many of them could be avoided, as cardiovascular risk factors are largely reversible.

Epicardial adipose tissue (EAT) is defined as a fat depot localized between the myocardial surface and the visceral layer of the pericardium, and is a type of visceral fat [4] Therefore, as is the case with abdominal obesity, EAT is one of the most important risk factors for atherosclerosis and cardiovascular events [5-7]. Moreover, the volume and thickness of EAT correlate with intra-abdominal fat mass and severity of obesity [8,9] and are independently associated with cardiovascular events [10]. Additionally, there are reports that EAT may be a new therapeutic target in CVDs [11,12].

The most common classification of the adipose tissue surrounding the heart includes (i) epicardial adipose tissue, (ii) pericardial adipose tissue, (iii) paracardial adipose tissue, 
and (iv) perivascular adipose tissue (Figure 1). Epicardial fat is located below the visceral pericardium. Pericardial fat consists of adipose tissues between the visceral and parietal pericardial layers and the fat depot on the external surface of the parietal pericardium. Paracardial fat involves fat deposits outside the parietal pericardium. The perivascular adipose tissue is a fat around the coronary arteries, irrespective of location [13].

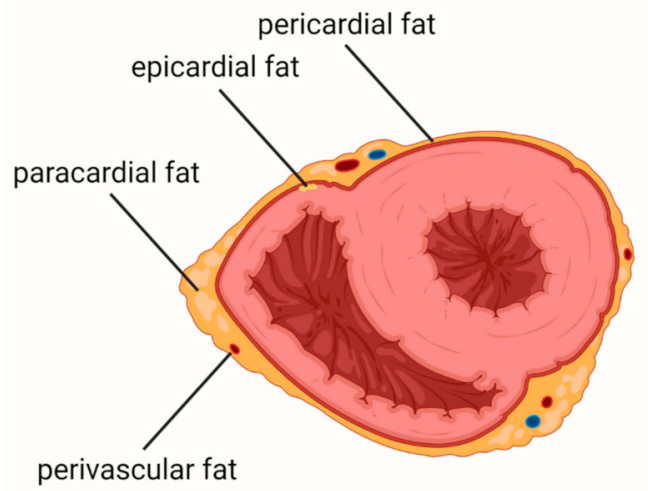

Figure 1. Adipose tissue surrounding the heart.

There are many differences between EAT and other types of adipose tissue, including anatomical, histological, embryological, and genetic differences $[14,15]$. EAT is located between the pericardium and the myocardium [5] and is not separated from the myocardium and vessels by fascia, allowing paracrine or vasocrine effects [16] via cytokines and chemokines [17]. In health conditions, EAT has a protective function, including protection against hypothermia [18] or mechanical protection for the coronary circulation [19]. Additionally, EAT has an important role in energy supply to the myocardium [20]. Thanks to the ability to use free fatty acid (FFA) quickly, EAT may protect the myocardium from the cardiotoxic effect of a large amount of FFA [21]. The secretion of adiponectin from epicardial adipocytes is also an important function of EAT. Adiponectin protects coronary circulation, improves endothelial function, reduces oxidative stress, and indirectly decreases the level of interleukin-6 (IL-6) and C-reactive protein (CRP) [22-24]. However, under specific conditions such as obesity, metabolic syndrome, or diabetes mellitus, the protective properties may be destroyed and EAT becomes a deleterious tissue promoting the development of CVDs. The most data on the transition of EAT's role is based on the observations of patients with coronary artery disease (CAD). For example, in one of our studies we showed a difference in gene expression in pericoronary adipose tissue in patients with and without CAD [25].

In this article, we summarize the currently available evidence regarding the role of EAT in the development of CVDs, including CAD, heart failure (HF) and atrial fibrillation (AF). Due to the rapid development of the COVID-19 pandemic, we also summarize data regarding the association between EAT's function and the course of COVID-19. Finally, we present the potential therapeutic possibilities aiming at modifying EAT's function in CVD. The role of EAT in the development of CVDs and COVID-19 is summarized in Figure 2. 


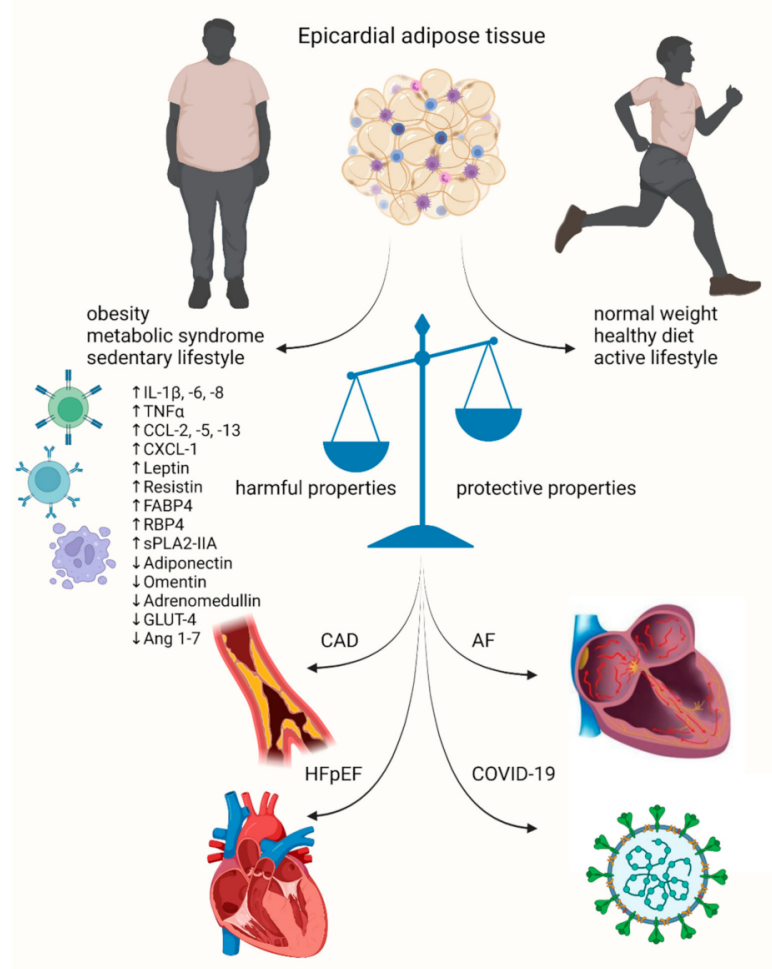

Figure 2. The role of epicardial adipose tissue in the development of cardiovascular diseases and cardiovascular complications in the course of COVID-19. AF-atrial fibrillation; Ang 1-7-angiotensin 1-7; CAD—coronary artery disease; CCL-2, -5, -13—chemokine ligand-2, -5, -13; CXCL-1— chemokine ligand 1; FABP4 - fatty acid binding protein 4; GLUT-4 - glucose transporter type 4; HFpEF-heart failure with preserved ejection fraction; IL- $1 \beta,-6,-8$-interleukin- $1 \beta,-6,-8$; RBP4 — retinol binding protein 4 ; sPLA2-IIA—secretory phospholipase A2; TNF $\alpha$-tumor necrosis factor $\alpha$.

\section{Coronary Artery Disease}

It has been shown that EAT and CAD are closely related at different levels: (i) in patients with CAD, the secretion of adipokines from EAT is altered; (ii) EAT has a proinflammatory features in patients with CVD risk factors and/or CAD; (iii) the amount of EAT and/or its proinflammatory state correlate with the severity of CAD and the instability of the atherosclerotic plaques; (iv) there is a relationship between EAT's function and coronary microvascular dysfunction and artery spasm [14,17,26-49].

In patients with obesity, metabolic syndrome, or $\mathrm{CAD}$, the epicardial adipocytes secrete less adiponectin and more leptin than in healthy people [26,27]. The decreased adiponectin expression attenuates endothelial function and leads to increased tumor necrosis factor- $\alpha$ $(\mathrm{TNF}-\alpha)$ production, which increases inflammation and oxidative stress. The increased leptin level promotes adhesion of monocytes, macrophage-to-foam cell transformation, and unfavorable changes in lipid and inflammatory cytokine levels in adipose tissue [28]. All these processes result in the development and destabilization of atherosclerotic plaques [29].

Inflammation plays a crucial role in atherosclerosis, and EAT as a tissue with proinflammatory properties provides a huge contribution to coronary plaque formation $[14,17,30,31]$. For example, Mazurek et al. showed that plasma inflammatory biomarkers did not adequately reflect local tissue inflammation [17]. Proinflammatory properties of EAT were noted irrespective of clinical variables (diabetes, body mass index, and chronic use of statins or angiotensin receptor enzyme inhibitors/angiotensin II receptor blockers) or plasma concentrations of circulating biomarkers. [17]. Autopsy studies have shown the presence of inflammatory cells in the adventitia in patients with acute coronary syndrome [32]. 
Furthermore, there was a correlation between the degree of severity of the lesion and the intensification of the inflammatory infiltration in the adventitia [32].

Wang et al. assessed EAT in computed tomography (CT) in patients with and without diabetes, showing that EAT volume (EATV) is higher in diabetic patients and is associated with components of metabolic syndrome, coronary atherosclerosis, and coronary calcium scores [33]. In the Framingham Study, a significant association was found between epicardial fat and coronary artery calcification, which was significant after adjustment for traditional cardiovascular risk factors [34]. Alexopoulos et al. showed that EATV increased significantly with the severity of luminal coronary stenosis and was larger in patients with mixed or noncalcified plaques, compared to patients with calcified plaques or no plaques, indicating the association between EAT and the most dangerous plaque phenotype [35]. This association has been confirmed in other studies [36-38]. Yamashita et al. showed that EATV, assessed by $\mathrm{CT}$, is associated with the total coronary plaque burden. Higher EATV was associated with a higher vulnerability of atherosclerotic plaques, based on the evaluation of atherosclerotic plaque composition by intravascular ultrasound imaging (IVUS) [36]. Mazurek et al. made a qualitative assessment of pericoronary adipose tissue (PCAT) using positron emission tomography/computed tomography (PET/CT) among patient with acute coronary syndrome without persistent ST-segment elevation [37] and with stable CAD [38]. In the first study, the inflammatory activity of PCAT, reflected by maximum fluorodeoxyglucose (FDG) uptake, was greater than the activity of adipose tissue in other locations [37]. There was also a correlation between the severity of atherosclerosis and the necrotic core volume of coronary plaque, as assessed by virtual histology IVUS [37]. Similar results were obtained in patients with stable CAD [38]. In another study, EAT thickness was associated with the Thrombolysis in Myocardial Infarction risk score in unstable angina and non-ST-elevation myocardial infarction [39]. Otsuka et al. demonstrated that EATV is associated with the presence of high-risk plaques, the so-called low attenuation plaques in CT, regardless of the presence of abdominal obesity [40]. Patients with higher visceral fat had a greater total plaque volume and a greater level of low-attenuation plaques [40]. Another study assessed the PCAT mean attenuation (PCAT-MA) based on $\mathrm{CT}$ as a measure of inflammation in EAT in patients with CAD [41]. PCAT-MA was higher in coronary arteries with plaque compared to vessels without plaque. The lesion-specific PCAT-MA was higher in noncalcified and mixed plaques compared to calcified plaques. These results suggest that lesion-specific PCAT-MA is related to plaque development and vulnerability [41]. In patients with acute myocardial infarction (MI), PCAT attenuation did not differentiate between the coronary segments with and without culprit lesions, but PCAT volume was strongly and independently associated with culprit lesions [42]. In contrast, Goeller et al. showed that PCAT attenuation was increased around culprit lesions compared with nonculprit lesions among patients with acute coronary syndrome [43]. In stable CAD patients, an increase in PCAT attenuation was associated with progression of noncalcified plaque burden and vice versa [44]. Nogic et al. reported that a higher lesion-specific PCAT attenuation baseline may predict in-stent restenosis among patients undergoing elective percutaneous coronary intervention [45]. Altogether, these results confirm that the amount of EAT and/or EAT proinflammatory state correlate with the severity of $\mathrm{CAD}$ and plaque vulnerability.

In women with chest pain and angiographically normal coronary arteries, there was a correlation between EAT thickness and reduced coronary flow reserve [46]. Kanaji et al. showed that in CAD patients with a single de novo lesion, PCAT attenuation is significantly associated with global coronary flow reserve [47]. Pasqualetto et al. suggested an association between PCAT attenuation in CT with coronary microvascular dysfunction; however, a significant correlation was found only in patients without severe obstructive CAD [48]. Another study found that EAT might be associated with coronary artery spasms [49]. Further studies are needed to investigate the relationship between EAT/PCAT and coronary microvascular dysfunction and vasospastic angina. 
Finally, attention should be paid to the current tendency to study the relationship of CAD not only with the thickness and volume of EAT, but also with its structure and size of adipocytes $[50,51]$. One study has found that the size and degree of hypertrophy of the epicardial adipocytes are related to CAD severity [51].

\section{Heart Failure}

Among patients with HF, approximately 50\% have preserved ejection fraction (HF$\mathrm{pEF}$ ). HFpEF is a heterogeneous disease with a complex pathogenesis which is not fully understood. This complexity is due to the fact that it can be caused or exacerbated by a variety of comorbidities, including cardiac and extracardiac abnormalities. Thus, the group of patients with $\mathrm{HFpEF}$ is very diverse $[52,53]$. $\mathrm{HFpEF}$ is the most common myocardium disorder among obese patients [54]. Savji et al. showed that higher body mass index (BMI) is associated with higher risk of HFpEF than with HF with reduced ejection fraction (HFrEF), and that it was most pronounced among women [55]. Similarly, cardiometabolic features, including insulin resistance, were associated with a higher risk of future HFpEF than with HFrEF [55].

Based on the hitherto studies, it can be concluded that: (i) there is an association between EATV and the development of HfpEF; (ii) patients with HFpEF and obesity represent a distinct phenotype of the disease; (iii) EAT thickness or volume may have a greater impact on HFpEF than obesity per se; (iv) EAT participates in the pathogenesis of HfpEF due to EAT's proinflammatory properties, intensification of fibrosis, and influence on myocardial substrate utilization.

There were several studies that showed a correlation between the severity of left ventricle (LV) diastolic dysfunction and the volume of EAT [56-58]. A meta-analysis of 22 studies including 5682 patients also confirmed the correlation between EATV with myocardial diastolic function [59].

Patients with coexisting obesity and HFpEF had a different clinical phenotype than patients with HFpEF without obesity [60]. Obokata et al. compared patients with HFpEF and obesity, HPpEF without obesity, and a non-obese control group without HF [60]. Among obese HFpEF patients, diabetes and sleep apnea were more prevalent, whereas in the non-obese HFpEF patients, atrial fibrillation was more common. Additionally, the obese HFpEF patients had lower concentrations of $\mathrm{N}$-terminal prohormone of brain natriuretic peptide (NT-proBNP), compared to the non-obese cohort. Furthermore, subjects with the obese HFpEF phenotype had increased plasma volume, a higher rate of concentric LV remodeling, greater right ventricular (RV) dilatation, and a higher rate of RV dysfunction. Obese patients also displayed worse exercise capacity, more pronounced hemodynamic abnormalities during exercise, and impaired pulmonary vasodilation. EAT thickness assessed by echocardiography was $20 \%$ higher in the obese HF group compared to non-obese $\mathrm{HF}$, and $50 \%$ higher compared to the control group [60]. This, along with much greater biventricular hypertrophy, causes an increase in the total heart volume in obese patients, followed by pericardial dilation. If pericardial dilation is insufficient, there is greater coupling between the pericardium, right heart and left heart (interventricular dependance), and pericardial restraint, as showed by greater septal flattening and higher ratio of pressure in the right atrium to pulmonary capillary wedge pressure at rest and during exercise in patients with the obese HFpEF phenotype [60]. Increased EAT thickness may change myocardial substrate utilization, including increased oxygen consumption, impaired oxygen use, and increased dependance on fatty acid oxidation, and thus contributes to a reduction in cardiac reserve and aerobic capacity among obese HFpEF [60-62]. In addition, space limitations in the cardiac fossa due to increased EAT thickness may aggravate RV dysfunction and contribute to an increase in intracardiac pressures, especially during exercise [60].

Koepp et al. examined patients with the obese phenotype of HfpEF and divided them into increased EAT thickness ( $\geq 9 \mathrm{~mm}$ in echocardiography) and normal EAT thickness [63]. It has been demonstrated that obese HfpEF patients with increased EAT thickness have more pronounced hemodynamic derangements at rest and during exercise, including 
greater elevation in cardiac filling pressures, more severe pulmonary hypertension, and greater pericardial restraint than the obese HFpEF group with normal EAT thickness [63]. Additionally, peak oxygen consumption was $20 \%$ lower in patients with increased EAT compared to the normal EAT group [63]. Van Woerden et al. examined EAT in patients with the HF and LV ejection fraction (EF) $>40 \%$ (HFpEF and HF with mildly reduced EF) and in the healthy control group using cardiac magnetic resonance (CMR) [64]. It was shown that despite similar BMI, the HF group has significantly higher total and ventricular EATV compared to the control group, and there were no differences in atrial EATV between the groups. These results show that not obesity per se, but rather fat distribution, may contribute to HF development. Additionally, HF patients with AF and/or diabetes had more EAT than HF patients without these disorders. Patients with higher total EATV had higher plasma levels of troponin $\mathrm{T}$, creatine kinase muscle-brain fraction and glycated hemoglobin, and worse kidney function. There were no significant associations between EATV and NT-proBNP concentration. In the HF group, total EATV was positively correlated with LV end-systolic volume and with left and right atrial volume. On the contrary, global longitudinal and circumferential strain were negatively correlated with total EATV [64].

In obese patients with increased plasma volume, the ability of LV to dilate is insufficient, leading to cardiac overfilling and disproportionate increases in cardiac filling pressures. It seems that the inadequate ventricular distensibility is caused by cardiac fibrosis and microvascular rarefaction [65,66]. Moreover, the quantity of fibrosis assessed in CMR is associated with prognosis and outcomes in HFpEF [67]. Obese patients displayed more EAT [8,9] and therefore it seems likely that they were more exposed to cytokines released from the EAT reservoir. As previously noted, in patients with CVDs, the EAT reservoir becomes a site of deranged adipogenesis and a source of proinflammatory factors with deleterious effects on myocardium, including fibrosis. Packer et al. postulated that epicardial fat is a transducer of systemic metabolic disorders and a systemic inflammatory state caused by obesity on the heart [68]. Some researchers pointed to myocardial accumulation of triglycerides and myocardial fibrosis as the main causes of LV diastolic dysfunction [69-71]. Additionally, it has been shown that EAT can release vasoactive agents which, via vasa vasorum, reach the microvascular network and may reduce coronary flow reserve [72,73]. One of the most recent studies showed that EAT thickness was of prognostic value in patients with HFpEF, which may be due to increased mechanical restraint and secretion of proinflammatory and proatherogenic adipokines [74]. In contrast, in HFrEF, greater EAT thickness seems to have a protective role, while EAT thinning is associated with a worse prognosis [74]. It is suggested that measuring EAT thickness can be useful to classify patients with or at increased risk of heart failure [75].

Further studies are needed to better understand the influence of EAT on the pathogenesis of HFpEF and EAT's potential applicability as a target for novel drugs.

\section{Atrial Fibrillation}

$\mathrm{AF}$ is the most common arrythmia in the adult population in the world, and its prevalence is increasing. It is estimated that $\mathrm{AF}$ affects up to $4 \%$ of the population in Australia, Europe, and the USA [76]. The involvement of hemodynamic stress in the pathogenesis of AF is well-documented, and hypertension is the most common risk factor [77]. Valvular diseases also significantly contribute to the development of this arrhythmia [78]. These disorders cause the remodeling of heart chambers, including enlargement of the left atrium (LA) and an increase in LA pressure. Alleviation of hemodynamic stresses can reduce $\mathrm{AF}^{\prime}$ s burden $[77,78]$. However, there is a large group of patients with AF who do not have hypertension or valvular disease but do have the features of atrial myopathy (LA enlargement, increased LA pressure), as observed in imaging studies [79]. It is known that inflammation is associated with the development of atrial myopathy [80], including both inflammation in course of systemic inflammatory diseases [81-84] and metabolic disorders accompanied by adipose tissue inflammation [85,86]. The risk of developing AF is especially increased in rheumatoid arthritis [81] and psoriasis [82]. Among the metabolic 
diseases, special attention should be paid to obesity [85] and diabetes mellitus [86]. In these states, $\mathrm{AF}^{\prime}$ s burden was proportional to the severity of metabolic disorders, such as glycemic control [85-88].

The literature indicates several potential mechanisms linking EAT with $\mathrm{AF}$, including: (i) proinflammatory status of EAT; (ii) reactive oxygen species (ROS) released from EAT; (iii) fatty infiltration of the atrium; (iv) dysfunction of the autonomic nervous system in EAT.

AF and inflammation are closely associated [80-86]. EAT can release inflammatory factors and contribute to inflammation and fibrosis in the adjacent myocardium via paracrine signaling. It should be emphasized that EAT has some features of brown adipose tissue, such as the presence of the uncoupling protein-1, which is a thermogenic protein specific to brown adipocytes [89]. These properties are mainly expressed in conditions of health and low oxidative stress [90-92]. The healthy EAT is a source of adiponectin, which may reduce inflammation and fibrosis [91-94]. In obesity, EAT loses its protective properties and becomes a tissue with a proinflammatory profile, subsequently increasing the risk of atrial myopathy and AF [95-99]. Mazurek et al. showed that inflammatory activity of EAT reflected by maximal standardized uptake value of FDG in PET/CT was higher in patients with AF than in the control group and it was not related to BMI [100].

It has been suggested that ROS play an important role in the pathogenesis of AF [101,102]. EAT has been shown to be richer in ROS than other fat depots [103], but at the same time, this effect was reduced by adiponectin [93].

It also seems that fatty infiltration into atrial myocardium plays an important role in the pathogenesis of AF, as demonstrated by histological examinations [104]. Fatty infiltration was more pronounced in persistent AF, compared with paroxysmal AF [105]. EATV and fatty infiltration were associated with cardiac conduction abnormalities [106]. It was postulated that EAT can change electrophysiological features and ion currents by cytokine, adipokine, and adipocyte infiltration, causing electrical substrate formation for AF [107]. Opolski et al. showed that increased EATV along the LA assessed by CT was associated with AF after coronary artery bypass grafting [108].

It should be noted that EAT contains significant amounts of ganglionated plexi which are a part of the autonomic nervous system (ANS), which may play a role in the pathogenesis of AF $[109,110]$. The thickness of the EAT was related to ANS dysfunction [111], and catheter ablation of epicardial fat-reduced cardiac ANS activity, which makes it an interesting therapeutic perspective [112].

There are also several other less-understood potential mechanisms which may explain the involvement of EAT in the pathogenesis of AF, such as the local aromatase effect [113-115]. A significant positive correlation was determined between the total aromatase content of EAT and the occurrence/duration of triggered atrial arrhythmias [114]. Further mechanisms are pending investigation.

In clinical terms, the relationship between epicardial adipose tissue and AF is extremely interesting. Obesity is a well-known risk factor for AF [85] and every $1 \mathrm{~kg} / \mathrm{m}^{2}$ reduction in $\mathrm{BMI}$ reduces the risk of AF by about 7\% [116]. There is an association between the severity of obesity and the volume and thickness of EAT [8,9]. The relationship between AF and EAT has been investigated in many studies using noninvasive imaging methods such as transthoracic echocardiography, CT, or CMR, showing that: (i) the prevalence of AF is related to the volume/thickness of the EAT; (ii) EAT promotes AF persistence; (iii) higher EATV is associated with lower catheter ablation efficacy.

Results from the Framingham Heart Study involving 2317 patients who underwent CT showed that higher EATV was associated with $40 \%$ higher odds of AF and remained significant regardless of traditional risk factors including age, sex, MI, or HF [117]. Interestingly, there was no association between AF prevalence and adipose tissue elsewhere [117].

Chekakie et al. showed a relationship between EATV and both persistent and paroxysmal AF using CT imaging [118]. Patients with persistent AF had a higher EATV than patients with paroxysmal AF or sinus rhythm [118]. The same conclusions were reached by Batal et al., who suggested that EAT can promote AF persistence [119]. Muhib et al. 
showed similar results in patients with hypertrophic cardiomyopathy using CMR to assess EAT [120].

From a clinical point of view, Wong et al. [121] and Tsao et al. showed a strong relationship between EAT and AF recurrence after catheter ablation. Patients with higher EATV had worse outcomes and early AF recurrence after ablation [121,122].

Finally, two meta-analyses confirmed a relationship between AF and EAT [123,124]. Wong et al. showed the strongest association between persistent AF and EAT, but the association with paroxysmal AF was also significant [123]. Interestingly, the strength of associations between AF with EAT was greater than for between AF and abdominal or overall adiposity [123]. Gaeta et al., based on the analysis of seven imaging studies, demonstrated a $32 \mathrm{~mL}$ higher EATV between the AF group and patients with sinus rhythm [124], further indicating that EAT plays a crucial role in AF development and persistence.

\section{COVID-19}

COVID-19 is a complex multisystem infectious disease caused by the SARS-CoV-2 virus, which predominantly affects the lungs [125]. Since COVID-19 was first diagnosed in December 2019, it has caused a significant burden to healthcare systems worldwide. Therefore, there is an urgent need to investigate the pathophysiological mechanisms underlying COVID-19.

After more than a year of the COVID-19 pandemic, there are reports indicating a potential relationship between EATV and cardiovascular complications of SARS-CoV-2 infection. Systemic inflammation has a central role in the development and progression of COVID-19 [126,127], and there are several studies which have shown that inflammatory and thrombotic biomarkers such as D-dimer or ferritin predict the clinical severity of COVID-19 [128-130]. Growing evidence shows that obesity adversely affects the course of mortality due to COVID-19 [131]. In one study, it has been postulated that EAT may have immunomodulatory properties and may be a reservoir for SARS-CoV-2, thus facilitating the spread of the virus and enhancing the inflammatory response [132].

Studies conducted so far on a small number of patients suggest that EATV and attenuation in CT: (i) were independent predictors of severe and unfavorable COVID19 courses, including death; (ii) may be associated with cardiovascular complications in patients with COVID-19.

Abrishami et al. assessed inflammatory parameters (including CRP) and EAT (volume and density) by CT on admission in 100 patients with COVID-19 [133]. Patients were followed until death or discharge. The mortality rate was $17 \%$ and was higher in obese patients. Among laboratory tests, increased lactate dehydrogenase (LDH) and decreased platelet count were significantly associated with death. EATV was similar in patients who died and in those who survived, but EAT density was significantly lower in patients who died ( $p=0.79$ and $p=0.008$, respectively) [133]. Similar results were obtained by Deng et al. among patients aged 18 to 40. In addition, patients with severe COVID-19 had significantly higher EATV [134].

Iacobellis et al. assessed EAT thickness and density depending on the COVID-19 severity [135]. Patients with most severe course of COVID-19 had significantly greater EAT attenuation than those presenting with mild and moderate COVID-19 $(p \leq 0.01)$, but EAT thickness was similar in all patients [135].

Grodecki et al. examined the relationship of EAT quantified on CT with the severity of pneumonia and adverse outcomes among patients with COVID-19 [136]. The primary outcome was clinical deterioration (intensive care unit admission, invasive mechanical ventilation, or vasopressor therapy) or in-hospital death. Among 109 patients, the primary outcome occurred in $21.1 \%$ of patients, and both EATV and attenuation were independent predictors of clinical deterioration or death ( $p=0.011$ and $p=0.003$, respectively). The severity of pneumonia was also associated with these EAT parameters. Further, there was a correlation between EATV and CRP level and LDH level [136]. The results of the above-mentioned studies indicate that the assessment of EAT by CT may be useful in risk 
stratification in patients suffering from SARS-CoV-2 infection. However, all these studies were performed in small groups of patients $(n=41-109)$ and studies on larger groups are needed.

COVID-19 can cause myocardial injury and other cardiovascular complications, including acute myocarditis, pulmonary embolism, or acute heart failure [137-141]. The exact mechanism of heart damage in the course of SARS-CoV-2 infection is not fully understood, but it may occur directly or indirectly, or in both ways [137]. Some cardiovascular complications are asymptomatic during acute infection, but emerging data have reported on post-COVID-19 heart syndrome [142]. It has been suggested that low EAT density in CT may indicate myocardial injury, as it occurs mainly in severe and critical COVID-19 patients [143]. Wei et al. showed in a group of 400 patients with laboratory-confirmed COVID-19 that patients with COVID-19-associated myocardial injury had a history of CVDs, primarily hypertension, diabetes, hypercholesterolemia, and CAD. These patients had higher plasma concentrations of IL-6 and higher risk of adverse in-hospital events (death, invasive mechanical ventilation, admission to an intensive care unit). A chest CT performed on admission showed that these patients also had a higher EATV (139.1 vs. $92.6 \mathrm{~cm}^{2}, p=0.036$ ) and that EATV over $137.1 \mathrm{~cm}^{2}$ was a strong independent predictor for myocardial injury in patients with COVID-19 [144].

Based on hitherto studies, EATV and EAT density seem to either reflect or affect the overall course of COVID-19, including pulmonary and cardiovascular complication, but more studies are needed to elucidate the mechanisms underlying this association.

\section{Therapeutic Options to Affect EAT}

Since EAT affects the development and progression of CVDs, EAT is a promising therapeutic target in cardiovascular patients. However, none of the therapeutic tools available to date have been specifically developed for EAT. However, it has been shown that (i) lifestyle changes, (ii) bariatric surgery, and (iii) pharmacotherapy can reduce EATV $[145,146]$ by a pleiotropic or an off-target effect (Figure 3).

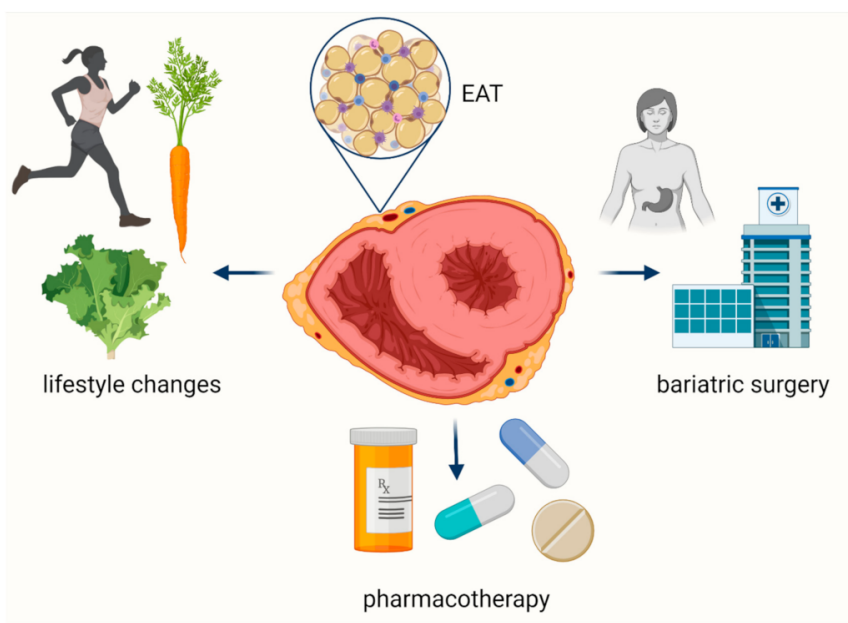

Figure 3. Therapeutic options to affect epicardial adipose tissue.

Both resistance [147,148] and endurance training reduce EATV [147,149,150]. Christensen et al. showed that physical activity can reduce EATV up to $32 \%$, as assessed by CMR [147]. The results of our pilot study in 30 amateur ultramarathon runners are in line with these data [151]. We found that ultrarunners have significantly lower CMR-assessed EATV than the sedentary control group, lower rate of pathologically high levels of plasma IL-6 (>1 pg/mL) and better lipid profile [151]. Therefore, the benefits of regular physical activity to reduce cardiovascular risk may extend beyond the traditional risk factors, as physical activity seems to modulate the EATV and activity. 
Another way to reduce EATV is diet [152-155]. Twenty severely obese subjects followed a 6-month weight-loss program with a very low-calorie diet, achieving a 33\% reduction in echocardiographic EAT thickness [155].

There are several small-group studies $(n=23$ to 65$)$ investigating the effect of bariatric surgery on EAT [156-159]. Two years after bariatric surgery, EAT thickness was reduced by $31 \%$ in a group of 51 operated patients, as assessed by echocardiography [159].

Although the positive effect of lifestyle modifications of EAT and overall cardiovascular health is clear, the compliance remains a concern. Therefore, pharmacotherapy remains a field of great interest regarding the modulation of EATV and function. The following groups of drugs were shown to affect EAT: (i) statins, (ii) antidiabetic drugs, (iii) anti-inflammatory drugs.

Statins have been shown to decrease EATV [160,161]. Alexopoulos et al. demonstrated that statin therapy leads to a reduction in EATV, and intensive therapy was more effective than moderate-intensity therapy in a group of 420 postmenopausal women with hyperlipidemia [160]. There was no correlation between EATV and lipid-lowering effect. Hence, this effect may have been secondary to anti-inflammatory effects of statins [160], which is consistent with the reports on EAT in patients with severe aortic stenosis [162]. Parisi et al. showed a relationship between statin therapy, EAT thickness reduction, and EAT inflammatory status, both in vivo and in vitro [162]. Raggi et al. indicated that statins reduce EAT attenuation in CT independent of their lipid-lowering effect, which indirectly indicates a reduction in EAT inflammation [163]. The clinical benefit of statin therapy in patients with CAD has been known for a long time [164]. However, the range of statin pleiotropic effects is growing, including their anti-inflammatory effects and modulation of EAT [164]. Tawakol et al. showed that statin therapy resulted in rapid, dose-dependent reductions in FDG uptake in PET/CT, representing changes in atherosclerotic plaque inflammation [165]. Even short-term intensive statin therapy significantly reduced the volume of EAT compared to placebo in patients with AF who underwent pulmonary vein isolation [161]. Hence, the anti-inflammatory effect of statins on EAT seems to reduce the risk of atrial myopathy, as demonstrated both in animal and human models [166,167]. The antiarrhythmic effect of statins was also confirmed in randomized trials and was most pronounced in the secondary prevention of AF [168-170]. Statins also ameliorate cardiac fibrosis, as demonstrated in animal models of HFpEF $[171,172]$. The positive effect of statin therapy on LV's diastolic function was also seen in clinical settings $[173,174]$. Statin use is also associated with a reduced risk of morbidity and mortality in patients with HF $[69,175]$. In patients with HFpEF, statin use was associated with reduced mortality $[176,177]$, which was confirmed in meta-analyses $[178,179]$. On the contrary, no benefit on clinical outcomes was observed in patients with HFrEF [180]. It has been suggested that statins can reduce EAT's metabolic activity [163]. With the exception of statins, Rivas Galvez et al. showed a significant reduction in thickness of EAT after 6 months of treatment with other lipid-lowering drugs, proprotein convertase subtilisin/kexin type 9 (PCSK-9) inhibitors [181]. All these data may suggest that statins and PCSK-9 inhibitors may exert their pleiotropic effects at least partly through EAT, although the underlying mechanisms of action are yet incompletely understood.

Another group of drugs that affect EAT are antidiabetic drugs, including thiazolidinediones, metformin, sodium-glucose cotransporter 2 (SGLT2) inhibitors, and incretin-based agents. Interest in antidiabetic drugs particularly increased after the publication of the results of the EMPA-REG and LEADER trials, which showed that SGLT2 inhibitors and glucagon-like peptide-1 receptor (GLP-1) agonists could have a cardioprotective effect by a mechanism independent of blood glucose level reduction [182,183]. The older groups of drugs (pioglitazone, metformin) also reduced the risk of cardiovascular complications in patients without diabetes, but with insulin resistance or pre-diabetes [184,185].

Metformin has been the most widely used antidiabetic drug for over 60 years. There is evidence of its anti-inflammatory effects on adipose tissue in diabetic and obese patients [186,187]. The anti-inflammatory effect of metformin has been confirmed by both its anti-aging and antitumor properties [188,189]. Similarly, pioglitazone was shown to 
reduce mast cells and inflammatory macrophages in adipose tissue [190,191]. These properties seem to be independent of the presence of diabetes mellitus [192]. Ziyrek et al. has shown that metformin monotherapy for 3 months reduced EAT thickness by 10\% [193]. The exact mechanism by which metformin interacts with EAT is not clear, but it appears to shift the metabolism into fat oxidation and upregulate the thermogenesis [193,194]. It has recently been shown to be effective against endothelial dysfunction [195]. Chen et al. reported that metformin reduced the secretion of the proinflammatory cytokine, activin A, from epicardial fat [196]. Sardu et al. showed that metformin reduced the inflammatory burden in PCAT and improved prognosis in prediabetic patients with acute MI treated with coronary artery bypass grafting [197]. Metformin through its pleiotropic effect influences the pathogenesis of many cardiovascular diseases [198,199]. One of the mechanisms underlying metformin's mode of action is the activation of adenosine monophosphate-activated protein kinase, which has an anti-inflammatory effect $[198,200]$. Studies performed in animal models indicated that SGLT2 inhibitors, GLP-1 agonists, and dipeptidyl peptidase-4 (DPP-4) inhibitors [201-203] have similar anti-inflammatory effects in adipose tissue, but further studies are needed to draw firm conclusions.

Thiazolidinediones are another group of drugs which reduce inflammation and the release of proinflammatory cytokines from EAT [204-206]. These effects may contribute to the reduced the risk of MI and stroke in patients treated with thiazolidinediones [207,208].

SGLT2 inhibitors were shown to reduce EATV assessed by CMR, among patients with type 2 diabetes, both with and without obesity [209-211]. SGLT2 inhibitors also improved the inflammatory status of EAT [209]. They have been documented to be effective against HF and endothelial dysfunction [212,213]. This group of drugs causes a significant reduction in body weight, and one of the mechanisms of action is the stimulation of visceral fat burn [214]. In one study, dapagliflozin caused a reduction in EAT thickness independent of weight loss [215], perhaps thanks to the improvement of EAT cells' sensitivity to insulin and a reduction in local proinflammatory chemokines secretion [216]. Although SGLT2 inhibitors are relatively new drugs, the first meta-analyses have already confirmed their beneficial impact on EAT [217].

Finally, incretin-based drugs, which include GLP-1 agonists and DPP-4 inhibitors, were also shown to reduce EAT thickness, measured by echocardiography [218] and EATV, assessed by CMR [219]. This effect was mainly weight-loss-dependent [219]. Importantly, despite the reduction in body weight, incretin-based drugs did not reduce the proinflammatory properties of adipose tissue [220,221], although they inhibited the development of atherosclerosis in animal models [222]. It has been shown that GLP-1 receptors are present in EAT, in contrast to subcutaneous adipose tissue [223]. Hence, it has been suggested that GLP-1 agonists affect EAT by stimulating pre-adipocyte differentiation, thermogenesis, and adipocyte browning [224,225]. DPP-4 inhibitors also reduce EAT thickness [226] but can have an adverse effect on its inflammatory status, which may stimulate myocardial fibrosis [227-229]. On the other hand, several studies have shown the anti-inflammatory properties of DPP-4 inhibitors [230-232]. These studies have suggested that these drugs downregulate the receptor for advanced glycation end-products [233], activate cyclic adenosine monophosphate/protein kinase A signaling and IL-6 production [234], and reduce ROS generation and intercellular adhesion molecule-1 expression [235].

Taking into account the inflammatory nature of atherosclerosis, three anti-inflammatory drugs are important in the context of EAT modulation: (i) canakinumab, (ii) methotrexate, and (iii) colchicine.

Canakinumab is a human anti-interleukin-1-beta (IL-1 $\beta$ ) monoclonal antibody which was shown to improve cardiovascular outcomes in over 10,000 patients with a history of CAD and elevated CRP levels in the CANTOS study [236]. Inhibition of the IL-1 $\beta /$ IL-6 signaling cascade with canakinumab led to a significant reduction in cardiovascular risk (nonfatal MI, nonfatal stroke, or cardiovascular death), independent of lipid-level lowering, but with an increased risk of serious infections [236]. Subgroup analysis showed that 
cardiovascular benefits were achieved due to a reduction in CRP concentration during canakinumab therapy [237].

Methotrexate reduces the proinflammatory effects of IL-6, IL-12, and TNF-alfa and increases the anti-inflammatory effects of IL-10 and IL-1 receptor antagonists [238]. In patients treated with methotrexate for rheumatoid conditions, it reduced the risk of MI by $18 \%$, according to a recent meta-analysis [239]. In the CIRT study that investigated the benefits of methotrexate on outcomes in patients with a history of acute coronary syndrome, MI, and diabetes or metabolic syndrome, no benefits regarding the composite endpoint including nonfatal MI, nonfatal stroke, and cardiovascular death were shown [240]. This is probably due to the fact that elevated CRP levels were not taken into account as an inclusion criterion, in contrast to the CANTOS study.

The efficacy of colchicine in patients with stable CAD was demonstrated by LoDoCo and LoDoCo2 studies [241,242]. In the LoDoCo study, a reduction in a composite endpoint consisting of MI, cardiac arrest, or noncardioembolic stroke was observed in colchicine group, compared to the placebo group [241]. In LoDoCo2 study, a significant reduction in the primary composite endpoint of cardiovascular death, nonprocedural MI, ischemic stroke, or ischemia-driven coronary revascularization was achieved in colchicine group, compared to the placebo [242]. The benefits of adding colchicine to standard therapy were also shown in COLCOT study, which included patients with a history of MI within the last month [243]. The primary efficacy endpoint (a composite of cardiovascular death, resuscitated cardiac arrest, MI, stroke, or urgent hospitalization for angina requiring coronary revascularization) occurred in $5.5 \%$ in the colchicine group compared to $7.1 \%$ in the placebo group $(p=0.02)$ [242]. Adding colchicine to standard therapy led to a lower risk of ischemic cardiovascular events, compared to the placebo.

Hitherto, there have been no studies evaluating the effects of canakinumab, methotrexate, and colchicine on EAT. Further reports on new drugs affecting EAT and inflammatory mechanisms are expected in the near future. Potential pharmacological therapeutic options are summarized in Table 1.

Table 1. Pharmacological therapeutic options to affect epicardial adipose tissue.

\begin{tabular}{|c|c|}
\hline \multicolumn{2}{|r|}{ Pharmacological Therapeutic Options } \\
\hline Group of Drugs & Potential Mechanisms of Action \\
\hline Statins & $\begin{array}{l}\text { anti-inflammatory [160,162-165] } \\
\text { modulation of EAT [164] } \\
\downarrow \text { EAT metabolic activity [163] }\end{array}$ \\
\hline PCSK-9 inhibitors & unknown \\
\hline Metformin & $\begin{array}{l}\text { anti-inflammatory }[186,187,196-198,200] \\
\uparrow \text { fat oxidation and thermogenesis }[193,194] \\
\downarrow \text { endothelial dysfunction }[195] \\
\text { activation of adenosine monophosphate-activated protein kinase }[198,200]\end{array}$ \\
\hline Thiazolidinediones & anti-inflammatory $[190,191,204-206]$ \\
\hline SGLT2 inhibitors & $\begin{array}{l}\text { anti-inflammatory [210,217] } \\
\downarrow \text { endothelial dysfunction [213] } \\
\text { stimulation of visceral fat burn [215] } \\
\uparrow \text { EAT cells sensitivity to insulin [217] }\end{array}$ \\
\hline GLP-1 agonists & $\begin{array}{l}\uparrow \text { pre-adipocyte differentiation [225] } \\
\uparrow \text { thermogenesis [226] } \\
\uparrow \text { adipocyte browning [226] }\end{array}$ \\
\hline DPP-4 inhibitors & $\begin{array}{l}\text { anti-inflammatory [231-233] } \\
\text { downregulation of the receptor for advanced glycation end-products [234] } \\
\uparrow \text { cyclic adenosine monophosphate/protein kinase A signaling and IL-6 production [235] } \\
\downarrow \text { ROS generation and intercellular adhesion molecule-1 expression [236] }\end{array}$ \\
\hline
\end{tabular}


Table 1. Cont.

\begin{tabular}{cc}
\hline & \multicolumn{1}{c}{ Pharmacological Therapeutic Options } \\
\hline Group of Drugs & Potential Mechanisms of Action \\
\hline Canakinumab & anti-inflammatory [237] \\
\hline Methotrexate & anti-inflammatory [239] \\
\hline Colchicine & anti-inflammatory [242,243] \\
\hline & EAT-epicardial adipose tissue; DPP-4—dipeptidyl peptidase-4; GLP-1-glucagon-like peptide-1 receptor; \\
& ROS-reactive oxygen species; SGLT2-sodium-glucose cotransporter 2.
\end{tabular}

\section{Conclusions}

EAT is not only an adipose tissue in the histological sense, but is above all a metabolically active tissue, modulating numerous pathophysiological processes in the course of CVDs. In presence of cardiovascular risk factors, the protective properties of EAT are destroyed and it becomes a pro-inflammatory tissue promoting the development and progression of CVDs including CAD, heart failure, arrhythmias, and cardiovascular complications of COVID-19. EAT's function can be modulated and potentially restored by changing the lifestyle and anti-inflammatory drugs. The development of novel therapies specifically targeting EAT might revolutionize the prognosis in patients with CVD. The search for potential drug targets in EAT is an exciting challenge we currently face.

Author Contributions: Conceptualization, M.K.; writing-original draft preparation, M.K.; writing-review and editing, A.G. and T.M.; visualization, M.K. and A.G.; supervision, T.M. and G.O. and M.G. All authors have read and agreed to the published version of the manuscript.

Funding: This research received no external funding.

Institutional Review Board Statement: Not applicable.

Data Availability Statement: Not applicable.

Conflicts of Interest: The authors report no conflict of interest related to this study.

\section{References}

1. Virani, S.S.; Alonso, A.; Benjamin, E.J.; Bittencourt, M.S.; Callaway, C.W.; Carson, A.P.; Chamberlain, A.M.; Chang, A.R.; Cheng, S.; Delling, F.N.; et al. Heart Disease and Stroke Statistics-2020 Update: A Report From the American Heart Association. Circulation 2020, 141, e139-e596. [CrossRef] [PubMed]

2. Heron, M. Deaths: Leading Causes for 2013. Natl. Vital Stat. Rep. 2016, 68, 1-77.

3. Fryar, C.D.; Chen, T.-C.; Li, X. Prevalence of Uncontrolled Risk Factors for Cardiovascular Disease: United States, 1999-2010. NCHS Data Brief. 2012, 103, 1-8.

4. Sacks, H.S.; Fain, J.N. Human epicardial adipose tissue: A review. Am. Heart J. 2007, 153, 907-917. [CrossRef] [PubMed]

5. Mathieu, P.; Pibarot, P.; Larose, É.; Poirier, P.; Marette, A.; Després, J.-P. Visceral obesity and the heart. Int. J. Biochem. Cell Biol. 2008, 40, 821-836. [CrossRef]

6. Mathieu, P.; Lemieux, I.; Després, J.-P. Obesity, Inflammation, and Cardiovascular Risk. Clin. Pharmacol. Ther. 2010, 87, 407-416. [CrossRef]

7. Després, J.-P.; Lemieux, I. Abdominal obesity and metabolic syndrome. Nature 2006, 444, 881-887. [CrossRef]

8. Rabkin, S.W. Epicardial fat: Properties, function and relationship to obesity. Obes. Rev. 2007, 8, 253-261. [CrossRef]

9. Iacobellis, G.; Willens, H.J.; Barbaro, G.; Sharma, A.M. Threshold values of high-risk echocardiographic epicardial fat thickness. Obesity 2008, 16, 887-892. [CrossRef]

10. Mahabadi, A.A.; Berg, M.H.; Lehmann, N.; Kälsch, H.; Bauer, M.; Kara, K.; Dragano, N.; Moebus, S.; Jöckel, K.-H.; Erbel, R.; et al. Association of Epicardial Fat with Cardiovascular Risk Factors and Incident Myocardial Infarction in the General Population. J. Am. Coll. Cardiol. 2013, 61, 1388-1395. [CrossRef]

11. Mazurek, T.; Opolski, G. Pericoronary Adipose Tissue: A Novel Therapeutic Target in Obesity-Related Coronary Atherosclerosis. J. Am. Coll. Nutr. 2015, 34, 244-254. [CrossRef] [PubMed]

12. Mazurek, K.; Zmijewski, P.; Krawczyk, K.; Czajkowska, A.; Kęska, A.; Kapuściński, P.; Mazurek, T. High intensity interval and moderate continuous cycle training in a physical education programme improves health-related fitness in young females. Biol. Sport 2016, 33, 139-144. [CrossRef] [PubMed] 
13. Nagy, E.; Jermendy, A.L.; Merkely, B.; Maurovich-Horvat, P. Clinical importance of epicardial adipose tissue. Arch. Med Sci. 2017, 4, 864-874. [CrossRef] [PubMed]

14. Zhang, L.; Zalewski, A.; Liu, Y.; Mazurek, T.; Cowan, S.; Martin, J.L.; Hofmann, S.M.; Vlassara, H.; Shi, Y. Diabetes-Induced Oxidative Stress and Low-Grade Inflammation in Porcine Coronary Arteries. Circulation 2003, 108, 472-478. [CrossRef] [PubMed]

15. McAninch, E.; Fonseca, T.L.; Poggioli, R.; Panos, A.; Salerno, T.A.; Deng, Y.; Li, Y.; Bianco, A.; Iacobellis, G. Epicardial adipose tissue has a unique transcriptome modified in severe coronary artery disease. Obesity 2015, 23, 1267-1278. [CrossRef]

16. Iacobellis, G. Local and systemic effects of the multifaceted epicardial adipose tissue depot. Nat. Rev. Endocrinol. 2015, 11, 363-371. [CrossRef]

17. Mazurek, T.; Zhang, L.; Zalewski, A.; Mannion, J.D.; Diehl, J.T.; Arafat, H.; Sarov-Blat, L.; O’Brien, S.; Keiper, E.A.; Johnson, A.G.; et al. Human Epicardial Adipose Tissue Is a Source of Inflammatory Mediators. Circulation 2003, 108, 2460-2466. [CrossRef]

18. Sacks, H.S.; Fain, J.N.; Holman, B.; Cheema, P.; Chary, A.; Parks, F.; Karas, J.; Optican, R.; Bahouth, S.W.; Garrett, E.; et al Uncoupling Protein-1 and Related Messenger Ribonucleic Acids in Human Epicardial and Other Adipose Tissues: Epicardial Fat Functioning as Brown Fat. J. Clin. Endocrinol. Metab. 2009, 94, 3611-3615. [CrossRef]

19. Prati, F.; Arbustini, E.; Labellarte, A.; Sommariva, L.; Pawlowski, T.; Manzoli, A.; Pagano, A.; Motolese, M.; Boccanelli, A. Eccentric atherosclerotic plaques with positive remodelling have a pericardial distribution: A permissive role of epicardial fat? A three-dimensional intravascular ultrasound study of left anterior descending artery lesions. Eur. Heart J. 2003, 24, 329-336. [CrossRef]

20. Iacobellis, G.; Bianco, A. Epicardial adipose tissue: Emerging physiological, pathophysiological and clinical features. Trends Endocrinol. Metab. 2011, 22, 450-457. [CrossRef]

21. Iozzo, P. Metabolic toxicity of the heart: Insights from molecular imaging. Nutr. Metab. Cardiovasc. Dis. 2010, 20, 147-156. [CrossRef] [PubMed]

22. Li, R.; Wang, W.-Q.; Zhang, H.; Yang, X.; Fan, Q.; Christopher, T.A.; Lopez, B.L.; Tao, L.; Goldstein, B.J.; Gao, F.; et al. Adiponectin improves endothelial function in hyperlipidemic rats by reducing oxidative/nitrative stress and differential regulation of eNOS/iNOS activity. Am. J. Physiol. Metab. 2007, 293, E1703-E1708. [CrossRef]

23. Deng, G.; Long, Y.; Yum, Y.R.; Li, M.R. Adiponectin directly improves endothelial dysfunction in obese rats through the AMPK-eNOS pathway. Int. J. Obes. 2010, 34, 165-171. [CrossRef] [PubMed]

24. Niedziela, M.; Wojciechowska, M.; Zarębiński, M.; Cudnoch-Jędrzejewska, A.; Mazurek, T. Adiponectin promotes ischemic heart preconditioning-PRO and CON. Cytokine 2020, 127, 154981. [CrossRef] [PubMed]

25. Konwerski, M.; Gromadka, A.; Arendarczyk, A.; Koblowska, M.; Iwanicka-Nowicka, R.; Wilimski, R.; Czub, P.; Filipiak, K.J.; Hendzel, P.; Zielenkiewicz, P.; et al. Atherosclerosis Pathways are Activated in Pericoronary Adipose Tissue of Patients with Coronary Artery Disease. J. Inflamm. Res. 2021, 14, 5419-5431. [CrossRef] [PubMed]

26. Eiras, S.; Teijeira-Fernández, E.; Shamagian, L.G.; Fernandez, A.L.; Vazquez-Boquete, A.; Gonzalez-Juanatey, J.R. Extension of coronary artery disease is associated with increased IL- 6 and decreased adiponectin gene expression in epicardial adipose tissue. Cytokine 2008, 43, 174-180. [CrossRef]

27. Iacobellis, G.; Pistilli, D.; Gucciardo, M.; Leonetti, F.; Miraldi, F.; Brancaccio, G.; Gallo, P.; Di Gioia, C.R.T. Adiponectin expression in human epicardial adipose tissue in vivo is lower in patients with coronary artery disease. Cytokine 2005, 29, 251-255. [CrossRef]

28. Raman, P.; Khanal, S. Leptin in Atherosclerosis: Focus on Macrophages, Endothelial and Smooth Muscle Cells. Int. J. Mol. Sci. 2021, 22, 5446. [CrossRef]

29. Iacobellis, G.; Malavazos, A.E.; Corsi, M.M. Epicardial fat: From the biomolecular aspects to the clinical practice. Int. J. Biochem. Cell Biol. 2011, 43, 1651-1654. [CrossRef]

30. Wolf, D.; Ley, K. Immunity and Inflammation in Atherosclerosis. Circ. Res. 2019, 124, 315-327. [CrossRef]

31. Virmani, R.; Burke, A.P.; Farb, A.; Kolodgie, F.D. Pathology of the vulnerable plaque. J. Am. Coll. Cardiol. 2006, 47, C13-C18. [CrossRef] [PubMed]

32. Tavora, F.; Kutys, R.; Li, L.; Ripple, M.; Fowler, D.; Burke, A. Adventitial lymphocytic inflammation in human coronary arteries with intimal atherosclerosis. Cardiovasc. Pathol. 2010, 19, e61-e68. [CrossRef]

33. Wang, C.P.; Hsu, H.L.; Hung, W.C.; Yu, T.H.; Chen, Y.H.; Chiu, C.A.; Lu, L.F.; Chung, F.M.; Shin, S.J.; Lee, Y.J. Increased epicardial adipose tissue (EAT) volume in type 2 diabetes mellitus and association with metabolic syndrome and severity of coronary atherosclerosis. Clin. Endocrinol. 2009, 70, 876-882. [CrossRef] [PubMed]

34. Rosito, G.A.; Massaro, J.M.; Hoffmann, U.; Ruberg, F.L.; Mahabadi, A.A.; Vasan, R.S.; O’Donnell, C.J.; Fox, C.S. Pericardial fat, visceral abdominal fat, cardiovascular disease risk factors, and vascular calcification in a community-based sample: The Framingham Heart Study. Circulation 2008, 117, 605-613. [CrossRef] [PubMed]

35. Alexopoulos, N.; McLean, D.S.; Janik, M.; Arepalli, C.D.; Stillman, A.E.; Raggi, P. Epicardial adipose tissue and coronary artery plaque characteristics. Atherosclerosis 2010, 210, 150-154. [CrossRef] [PubMed]

36. Yamashita, K.; Yamamoto, M.H.; Igawa, W.; Ono, M.; Kido, T.; Ebara, S.; Okabe, T.; Saito, S.; Amemiya, K.; Isomura, N.; et al. Association of Epicardial Adipose Tissue Volume and Total Coronary Plaque Burden in Patients with Coronary Artery Disease. Int. Heart J. 2018, 59, 1219-1226. [CrossRef] 
37. Mazurek, T.; Kochman, J.; Kobylecka, M.; Wilimski, R.; Filipiak, K.J.; Krolicki, L.; Opolski, G. Inflammatory activity of pericoronary adipose tissue may affect plaque composition in patients with acute coronary syndrome without persistent ST-segment elevation: Preliminary results. Kardiol. Pol. 2013, 72, 410-416. [CrossRef]

38. Mazurek, T.; Kobylecka, M.; Zielenkiewicz, M.; Kurek, A.; Kochman, J.; Filipiak, K.J.; Mazurek, K.; Huczek, Z.; Królicki, L.; Opolski, G. PET/CT evaluation of 18F-FDG uptake in pericoronary adipose tissue in patients with stable coronary artery disease: Independent predictor of atherosclerotic lesions' formation? J. Nucl. Cardiol. 2016, 24, 1075-1084. [CrossRef]

39. Özcan, F.; Turak, O.; Canpolat, U.; Kanat, S.; Kadife, I.; Avc1, S.; Işleyen, A.; Cebeci, M.; Tok, D.; Başar, F.; et al. Association of epicardial fat thickness with TIMI risk score in NSTEMI/USAP patients. Herz 2014, 39, 755-760. [CrossRef]

40. Otsuka, K.; Ishikawa, H.; Yamaura, H.; Shirasawa, K.; Kasayuki, N. Epicardial adipose tissue volume is associated with lowattenuation plaque volume in subjects with or without increased visceral fat: A 3-vessel coronary artery analysis with CT angiography. Eur. Heart J. 2021, 42 (Suppl. 1), ehab724-0208. [CrossRef]

41. Ma, R.; van Assen, M.; Ties, D.; Pelgrim, G.J.; van Dijk, R.; Sidorenkov, G.; van Ooijen, P.M.A.; van der Harst, P.; Vliegenthart, R. Focal pericoronary adipose tissue attenuation is related to plaque presence, plaque type, and stenosis severity in coronary CTA. Eur. Radiol. 2021, 31, 7251-7261. [CrossRef] [PubMed]

42. Balcer, B.; Dykun, I.; Schlosser, T.; Forsting, M.; Rassaf, T.; Mahabadi, A.A. Pericoronary fat volume but not attenuation differentiates culprit lesions in patients with myocardial infarction. Atherosclerosis 2018, 276, 182-188. [CrossRef] [PubMed]

43. Goeller, M.; Achenbach, S.; Cadet, S.; Kwan, A.C.; Commandeur, F.; Slomka, P.J.; Gransar, H.; Albrecht, M.H.; Tamarappoo, B.K.; Berman, D.S.; et al. Pericoronary Adipose Tissue Computed Tomography Attenuation and High-Risk Plaque Characteristics in Acute Coronary Syndrome Compared with Stable Coronary Artery Disease. JAMA Cardiol. 2018, 3, 858-863. [CrossRef] [PubMed]

44. Goeller, M.; Tamarappoo, B.K.; Kwan, A.C.; Cadet, S.; Commandeur, F.; Razipour, A.; Slomka, P.J.; Gransar, H.; Chen, X.; Otaki, Y.; et al. Relationship between changes in pericoronary adipose tissue attenuation and coronary plaque burden quantified from coronary computed tomography angiography. Eur. Heart J. Cardiovasc. Imaging 2019, 20, 636-643. [CrossRef]

45. Nogic, J.; Kim, J.; Layland, J.; Chan, J.; Cheng, K.; Wong, D.; Brown, A. TCT-241 Pericoronary Adipose Tissue Is a Predictor of In-Stent Restenosis and Stent Failure in Patients Undergoing Coronary Artery Stent Insertion. J. Am. Coll. Cardiol. 2021, 78 (19 Suppl. S), B98. [CrossRef]

46. Sade, L.E.; Eroglu, S.; Bozbaş, H.; Özbiçer, S.; Hayran, M.; Haberal, A.; Muderrisoglu, I.H. Relation between epicardial fat thickness and coronary flow reserve in women with chest pain and angiographically normal coronary arteries. Atherosclerosis 2009, 204, 580-585. [CrossRef]

47. Kanaji, Y.; Sugiyama, T.; Hoshino, M.; Misawa, T.; Nagamine, T.; Yasui, Y.; Nogami, K.; Ueno, H.; Hada, M.; Yamaguchi, M.; et al. The impact of pericoronary adipose tissue attenuation on global coronary flow reserve in patients with stable coronary artery disease. J. Am. Coll. Cardiol. 2021, 77, 1433. [CrossRef]

48. Pasqualetto, M.C.; Tuttolomondo, D.; Cutruzzolà, A.; Niccoli, G.; Dey, D.; Greco, A.; Martini, C.; Irace, C.; Rigo, F.; Gaibazzi, N. Human coronary inflammation by computed tomography: Relationship with coronary microvascular dysfunction. Int. J. Cardiol. 2021, 336, 8-13. [CrossRef]

49. Kataoka, T.; Harada, K.; Tanaka, A.; Onishi, T.; Matsunaga, S.; Funakubo, H.; Harada, K.; Nagao, T.; Shinoda, N.; Marui, N.; et al Relationship between epicardial adipose tissue volume and coronary artery spasm. Int. J. Cardiol. 2021, 324, 8-12. [CrossRef]

50. Aitken-Buck, H.M.; Moharram, M.; Babakr, A.A.; Reijers, R.; Van Hout, I.; Fomison-Nurse, I.C.; Sugunesegran, R.; Bhagwat, K.; Davis, P.J.; Bunton, R.W.; et al. Relationship between epicardial adipose tissue thickness and epicardial adipocyte size with increasing body mass index. Adipocyte 2019, 8, 412-420. [CrossRef]

51. Naryzhnaya, N.V.; Koshelskaya, O.A.; Kologrivova, I.V.; Kharitonova, O.A.; Evtushenko, V.V.; Boshchenko, A.A. Hypertrophy and Insulin Resistance of Epicardial Adipose Tissue Adipocytes: Association with the Coronary Artery Disease Severity. Biomedicines 2021, 9, 64. [CrossRef] [PubMed]

52. Reddy, Y.N.; Borlaug, B.A. Heart failure with preserved ejection fraction. Curr. Probl. Cardiol. 2016, 41, 145-188. [CrossRef] [PubMed]

53. Shah, S.J.; Kitzman, D.W.; Borlaug, B.A.; van Heerebeek, L.; Zile, M.R.; Kass, D.A.; Paulus, W.J. Phenotype-specific treatment of heart failure with preserved ejection fraction: A multiorgan roadmap. Circulation 2016, 134, 73-90. [CrossRef] [PubMed]

54. Kitzman, D.W.; Shah, S.J. The HFpEF obesity phenotype: The elephant in the room. J. Am. Coll. Cardiol. 2016, 68, 200-203. [CrossRef]

55. Savji, N.; Meijers, W.C.; Bartz, T.M.; Bhambhani, V.; Cushman, M.; Nayor, M.; Kizer, J.R.; Sarma, A.; Blaha, M.J.; Gansevoort, R.T.; et al. The Association of Obesity and Cardiometabolic Traits with Incident HFpEF and HFrEF. JACC Heart Fail. 2018, 6, 701-709. [CrossRef]

56. Fontes-Carvalho, R.; Fontes-Oliveira, M.; Sampaio, F.; Bettencourt, N.; Teixeira, M.; Rocha Gonçalves, F.; Gama, V.; Leite-Moreira, A. Influence of epicardial and visceral fat on left ventricular diastolic and systolic functions inpatients after myocardial infarction. Am. J. Cardiol. 2014, 114, 1663-1669. [CrossRef]

57. Liu, J.; Fox, C.S.; Hickson, D.A.; May, W.L.; Ding, J.; Carr, J.J.; Taylor, H.A. Pericardial fat and echocardiographic measures of cardiac abnormalities: The Jackson Heart Study. Diabetes Care 2011, 34, 341-346. [CrossRef]

58. Cavalcante, J.L.; Tamarappoo, B.K.; Hachamovitch, R.; Kwon, D.H.; Alraies, M.C.; Halliburton, S.; Schoenhagen, P.; Dey, D.; Berman, D.S.; Marwick, T.H. Association of Epicardial Fat, Hypertension, Subclinical Coronary Artery Disease, and Metabolic Syndrome with Left Ventricular Diastolic Dysfunction. Am. J. Cardiol. 2012, 110, 1793-1798. [CrossRef] 
59. Nerlekar, N.; Muthalaly, R.G.; Wong, N.; Thakur, U.; Wong, D.T.L.; Brown, A.J.; Marwick, T.H. Association of Volumetric Epicardial Adipose Tissue Quantification and Cardiac Structure and Function. J. Am. Heart Assoc. 2018, 7, e009975. [CrossRef]

60. Obokata, M.; Reddy, Y.; Pislaru, S.; Melenovsky, V.; Borlaug, B.A. Evidence Supporting the Existence of a Distinct Obese Phenotype of Heart Failure with Preserved Ejection Fraction. Circulation 2017, 136, 6-19. [CrossRef]

61. Peterson, L.R.; Herrero, P.; Schechtman, K.B.; Racette, S.; Waggoner, A.D.; Kisrieva-Ware, Z.; Dence, C.; Klein, S.; Marsala, J.; Meyer, T.; et al. Effect of Obesity and Insulin Resistance on Myocardial Substrate Metabolism and Efficiency in Young Women. Circulation 2004, 109, 2191-2196. [CrossRef]

62. Iacobellis, G.; Corradi, D.; Sharma, A.M. Epicardial adipose tissue: Anatomic, biomolecular and clinical relationships with the heart. Nat. Clin. Pract. Cardiovasc. Med. 2005, 2, 536-543. [CrossRef] [PubMed]

63. Koepp, K.E.; Obokata, M.; Reddy, Y.N.; Olson, T.P.; Borlaug, B.A. Hemodynamic and Functional Impact of Epicardial Adipose Tissue in Heart Failure with Preserved Ejection Fraction. JACC Heart Fail. 2020, 8, 657-666. [CrossRef] [PubMed]

64. Van Woerden, G.; Gorter, T.M.; Westenbrink, B.D.; Willems, T.P.; Van Veldhuisen, D.J.; Rienstra, M. Epicardial fat in heart failure patients with mid-range and preserved ejection fraction. Eur. J. Heart Fail. 2018, 20, 1559-1566. [CrossRef] [PubMed]

65. Mahajan, R.; Lau, D.H.; Sanders, P. Impact of obesity on cardiac metabolism, fibrosis, and function. Trends Cardiovasc. Med. 2015 25, 119-126. [CrossRef]

66. Mohammed, S.F.; Hussain, S.; Mirzoyev, S.A.; Edwards, W.D.; Maleszewski, J.J.; Redfield, M.M. Coronary Microvascular Rarefaction and Myocardial Fibrosis in Heart Failure With Preserved Ejection Fraction. Circulation 2015, 131, 550-559. [CrossRef]

67. Duca, F.; Kammerlander, A.A.; Zotter-Tufaro, C.; Aschauer, S.; Schwaiger, M.L.; Marzluf, B.A.; Bonderman, D.; Mascherbauer, J. Interstitial fibrosis, functional status, and outcomes in heart failure with preserved ejection fraction: Insights from a prospective cardiac magnetic resonance imaging study. Circ. Cardiovasc. Imaging 2016, 9, e005277. [CrossRef]

68. Packer, M. Epicardial Adipose Tissue May Mediate Deleterious Effects of Obesity and Inflammation on the Myocardium. J. Am. Coll. Cardiol. 2018, 71, 2360-2372. [CrossRef]

69. Ng, A.C.T.; Strudwick, M.; van der Geest, R.J.; Ng, A.C.C.; Gillinder, L.; Goo, S.Y.; Cowin, G.; Delgado, V.; Wang, W.Y.S.; Bax, J.J. Impact of epicardial adipose tissue, left ventricular myocardial fat content, and interstitial fibrosis on myocardial contractile function. Circ. Cardiovasc. Imaging 2018, 11, e007372. [CrossRef]

70. Antonopoulos, A.S.; Antoniades, C. Cardiac Magnetic Resonance Imaging of Epicardial and Intramyocardial Adiposity as an Early Sign of Myocardial Disease. Circ. Cardiovasc. Imaging 2018, 11, e008083. [CrossRef]

71. Nyman, K.; Granér, M.; Pentikäinen, M.O.; Lundbom, J.; Hakkarainen, A.; Sirén, R.; Nieminen, M.S.; Taskinen, M.-R.; Lundbom, N.; Lauerma, K. Cardiac steatosis and left ventricular function in men with metabolic syndrome. J. Cardiovasc. Magn. Reson. 2013, 15, 103. [CrossRef] [PubMed]

72. Nakanishi, K.; Fukuda, S.; Tanaka, A.; Otsuka, K.; Taguchi, H.; Shimada, K. Relationships Between Periventricular Epicardial Adipose Tissue Accumulation, Coronary Microcirculation, and Left Ventricular Diastolic Dysfunction. Can. J. Cardiol. 2017, 33, 1489-1497. [CrossRef] [PubMed]

73. Rabkin, S.W. Is reduction in coronary blood flow themechanism by which epicardial fat produces left ventricular diastolic dysfunction? Can. J. Cardiol. 2017, 33, 1459-1461. [CrossRef]

74. Pugliese, N.; De Biase, N.; Mazzola, M.; Paneni, F.; Del Punta, L.; Gargani, L.; Mengozzi, A.; Virdis, A.; Nesti, L.; Taddei, S.; et al. Prognostic significance of epicardial adipose tissue in heart failure with preserved and reduced ejection fraction. Eur. Heart $J$. 2021, 42 (Suppl. 1), ehab724-0820. [CrossRef]

75. Nyawo, T.A.; Dludla, P.V.; Mazibuko-Mbeje, S.E.; Mthembu, S.X.H.; Nyambuya, T.M.; Nkambule, B.B.; Gijsen, H.S.-V.; Strijdom, H.; Pheiffer, C. A systematic review exploring the significance of measuring epicardial fat thickness in correlation to B-type natriuretic peptide levels as prognostic and diagnostic markers in patients with or at risk of heart failure. Heart Fail. Rev. 2021, 1-11. [CrossRef] [PubMed]

76. Zulkifly, H.; Lip, G.Y.H.; Lane, D.A. Epidemiology of atrial fibrillation. Int. J. Clin. Pract. 2018, 72, e13070. [CrossRef]

77. Schneider, M.P.; Hua, T.A.; Böhm, M.; Wachtell, K.; Kjeldsen, S.E.; Schmieder, R.E. Prevention of Atrial Fibrillation by ReninAngiotensin System Inhibition: A Meta-Analysis. J. Am. Coll. Cardiol. 2010, 55, 2299-2307. [CrossRef] [PubMed]

78. Large, S.R.; Hosseinpour, A.R.; Wisbey, C.; Wells, F.C. Spontaneous cardioversion and mitral valve repair: A role for surgical cardioversion (Cox-maze)? Eur. J. Cardiothorac. Surg. 1997, 11, 76-80. [CrossRef]

79. Hirsh, B.J.; Copeland-Halperin, R.S.; Halperin, J.L. Fibrotic atrial cardiomyo-pathy, atrial fibrillation, and thromboembolism: Mechanistic links and clinical inferences. J. Am. Coll. Cardiol. 2015, 65, 2239-2251. [CrossRef]

80. Watanabe, T.; Takeishi, Y.; Hirono, O.; Itoh, M.; Matsui, M.; Nakamura, K.; Tamada, Y.; Kubota, I. C-Reactive protein elevation predicts the occurrence of atrial structural remodeling in patients with paroxysmal atrial fibrillation. Heart Vessel. 2005, 20, 45-49. [CrossRef]

81. Lindhardsen, J.; Ahlehoff, O.; Gislason, G.H.; Madsen, O.R.; Olesen, J.B.; Svendsen, J.H.; Torp-Pedersen, C.; Hansen, P.R. Risk of atrial fibrillation and stroke in rheumatoid arthritis: Danish nationwide cohort study. BMJ 2012, 344, e1257. [CrossRef] [PubMed]

82. Rhee, T.-M.; Lee, J.H.; Choi, E.-K.; Han, K.-D.; Lee, H.; Park, C.S.; Hwang, D.; Lee, S.-R.; Lim, W.-H.; Kang, S.-H.; et al. Increased Risk of Atrial Fibrillation and Thromboembolism in Patients with Severe Psoriasis: A Nationwide Population-based Study. Sci. Rep. 2017, 7, 9973. [CrossRef] [PubMed]

83. Aksoy, H.; Okutucu, S.; Sayin, B.Y.; Oto, A. Non-invasive electrocardiographic methods for assessment of atrial conduction heterogeneity in ankylosing spondylitis. Eur. Rev. Med. Pharmacol. Sci. 2016, 20, 2185-2186. [PubMed] 
84. Efe, T.H.; Cimen, T.; Ertem, A.G.; Coskun, Y.; Bilgin, M.; Sahan, H.F.; Pamukcu, H.E.; Yayla, C.; Sunman, H.; Yuksel, I.; et al. Atrial Electromechanical Properties in Inflammatory Bowel Disease. Echocardiography 2016, 33, 1309-1316. [CrossRef]

85. Wanahita, N.; Messerli, F.H.; Bangalore, S.; Gami, A.S.; Somers, V.K.; Steinberg, J.S. Atrial fibrillation and obesity-Results of a meta-analysis. Am. Heart J. 2008, 155, 310-315. [CrossRef]

86. Huxley, R.R.; Alonso, A.; Lopez, F.L.; Filion, K.; Agarwal, S.K.; Loehr, L.; Soliman, E.Z.; Pankow, J.; Selvin, E. Type 2 diabetes, glucose homeostasis and incident atrial fibrillation: The Atherosclerosis Risk in Communities study. Heart 2011, 98, 133-138. [CrossRef]

87. Graça, B.; Ferreira, M.J.; Donato, P.; Gomes, L.; Castelo-Branco, M.; Caseiro-Alves, F. Left atrial dysfunction in type 2 diabetes mellitus: Insights from cardiac MRI. Eur. Radiol. 2014, 24, 2669-2676. [CrossRef]

88. Nyman, K.; Graner, M.; Pentikäinen, M.; Lundbom, J.; Hakkarainen, A.; Siren, R.; Nieminen, M.; Taskinen, M.-R.; Lauerma, K.; Lundbom, N. Metabolic syndrome associates with left atrial dysfunction. Nutr. Metab. Cardiovasc. Dis. 2018, $28,727-734$. [CrossRef]

89. Chechi, K.; Voisine, P.; Mathieu, P.; Laplante, M.; Bonnet, S.; Picard, F.; Joubert, P.; Richard, D. Functional characterization of the Ucp1-associated oxidative phenotype of human epicardial adipose tissue. Sci. Rep. 2017, 7, 15566. [CrossRef]

90. Pezeshkian, M.; Noori, M.; Najjarpour-Jabbari, H.; Abolfathi, A.; Darabi, M.; Darabi, M.; Shaaker, M.; Shahmohammadi, G. Fatty acid composition of epicardial and subcutaneous human adipose tissue. Metab. Syndr. Relat. Disord. 2009, 7, 125-131. [CrossRef]

91. Kourliouros, A.; Karastergiou, K.; Nowell, J.; Gukop, P.; Hosseini, M.T.; Valencia, O.; Ali, V.M.; Jahangiri, M. Protective effect of epicardial adiponectin on atrial fibrillation following cardiac surgery. Eur. J. Cardio-Thoracic. Surg. 2011, 39, 228-232. [CrossRef] [PubMed]

92. Inoue, T.; Takemori, K.; Mizuguchi, N.; Kimura, M.; Chikugo, T.; Hagiyama, M.; Yoneshige, A.; Mori, T.; Maenishi, O.; Kometani, T.; et al. Heart-bound adiponectin, not serum adiponectin, inversely correlates with cardiac hypertrophy in strokeprone spontaneously hypertensive rats. Exp. Physiol. 2017, 102, 1435-1447. [CrossRef] [PubMed]

93. Antonopoulos, A.S.; Margaritis, M.; Verheule, S.; Recalde, A.; Sanna, F.; Herdman, L.; Psarros, C.; Nasrallah, H.; Coutinho, P.; Akoumianakis, I.; et al. Mutual regulation of epicardial adipose tissue and myocardial redox state by PPARgamma/adiponectin signalling. Circ Res. 2016, 118, 842-855. [CrossRef] [PubMed]

94. Fang, F.; Liu, L.; Yang, Y.; Tamaki, Z.; Wei, J.; Marangoni, R.G.; Bhattacharyya, S.; Summer, R.S.; Ye, B.; Varga, J. The adipokine adiponectin has potent anti-fibrotic effects mediated via adenosine monophosphate-activated protein kinase: Novel target for fibrosis therapy. Arthritis Res. Ther. 2012, 14, R229. [CrossRef] [PubMed]

95. Vural, B.; Atalar, F.; Ciftci, C.; Demirkan, A.; Susleyici-Duman, B.; Gunay, D.; Akpinar, B.; Sagbas, E.; Ozbek, U.; Buyukdevrim, A.S. Presence of fatty-acid-binding protein 4 expression in human epicardial adipose tissue in metabolic syndrome. Cardiovasc. Pathol. 2008, 17, 392-398. [CrossRef] [PubMed]

96. Kim, S.J.; Kim, H.S.; Jung, J.W.; Kim, N.S.; Noh, C.I.; Hong, Y.M. Correlation Between Epicardial Fat Thickness by Echocardiography and Other Parameters in Obese Adolescents. Korean Circ. J. 2012, 42, 471-478. [CrossRef] [PubMed]

97. Karastergiou, K.; Evans, I.; Ogston, N.; Miheisi, N.; Nair, D.; Kaski, J.-C.; Jahangiri, M.; Mohamed-Ali, V. Epicardial Adipokines in Obesity and Coronary Artery Disease Induce Atherogenic Changes in Monocytes and Endothelial Cells. Arter. Thromb. Vasc. Biol. 2010, 30, 1340-1346. [CrossRef]

98. Bambace, C.; Sepe, A.; Zoico, E.; Telesca, M.; Olioso, D.; Venturi, S.; Rossi, A.; Corzato, F.; Faccioli, S.; Cominacini, L.; et al. Inflammatory profile in subcutaneous and epicardial adipose tissue in men with and without diabetes. Heart Vessel. 2014, 29, 42-48. [CrossRef]

99. Cheng, K.-H.; Chu, C.-S.; Lee, K.-T.; Lin, T.-H.; Hsieh, C.-C.; Chiu, C.-C.; Voon, W.-C.; Sheu, S.-H.; Lai, W.-T. Adipocytokines and proinflammatory mediators from abdominal and epicardial adipose tissue in patients with coronary artery disease. Int. J. Obes. 2008, 32, 268-274. [CrossRef]

100. Mazurek, T.; Kiliszek, M.; Kobylecka, M.; Skubisz-Głuchowska, J.; Kochman, J.; Filipiak, K.; Krolicki, L.; Opolski, G. Relation of Proinflammatory Activity of Epicardial Adipose Tissue to the Occurrence of Atrial Fibrillation. Am. J. Cardiol. 2014, 113, 1505-1508. [CrossRef]

101. Tse, G.; Yan, B.P.; Chan, Y.W.F.; Tian, X.Y.; Huang, Y. Reactive oxygen species, endoplasmic reticulum stress and mitochondrial dysfunction: The link with cardiac arrhythmogenesis. Front. Physiol. 2016, 7, 313. [CrossRef] [PubMed]

102. Kim, Y.M.; Kattach, H.; Ratnatunga, C.; Pillai, R.; Channon, K.; Casadei, B. Association of Atrial Nicotinamide Adenine Dinucleotide Phosphate Oxidase Activity With the Development of Atrial Fibrillation After Cardiac Surgery. J. Am. Coll. Cardiol. 2008, 51, 68-74. [CrossRef] [PubMed]

103. Salgado-Somoza, A.; Teijeira-Fernández, E.; Fernández, Á.L.; González-Juanatey, J.R.; Eiras, S. Proteomic analysis of epicardial and subcutaneous adipose tissue reveals differences in proteins involved in oxidative stress. Am. J. Physiol. Heart Circ. Physiol. 2010, 299, H202-H209. [CrossRef]

104. Haemers, P.; Hamdi, H.; Guedj, K.; Suffee, N.; Farahmand, P.; Popovic, N.; Claus, P.; Leprince, P.; Nicoletti, A.; Jalife, J.; et al. Atrial fibrillation is associated with the fibrotic remodelling of adipose tissue in the subepicardium of human and sheep atria. Eur. Heart J. 2017, 38, 53-61. [CrossRef]

105. Platonov, P.; Mitrofanova, L.B.; Orshanskaya, V.; Ho, S.Y. Structural Abnormalities in Atrial Walls Are Associated with Presence and Persistency of Atrial Fibrillation But Not with Age. J. Am. Coll. Cardiol. 2011, 58, 2225-2232. [CrossRef] [PubMed] 
106. Friedman, D.; Wang, N.; Meigs, J.B.; Hoffmann, U.; Massaro, J.M.; Fox, C.S.; Magnani, J.W. Pericardial Fat is Associated with Atrial Conduction: The Framingham Heart Study. J. Am. Heart Assoc. 2014, 3, e000477. [CrossRef]

107. Zhou, M.; Wang, H.; Chen, J.; Zhao, L. Epicardial adipose tissue and atrial fibrillation: Possible mechanisms, potential therapies, and future directions. Pacing Clin. Electrophysiol. 2019, 43, 133-145. [CrossRef]

108. Opolski, M.P.; Staruch, A.D.; Kusmierczyk, M.; Witkowski, A.; Kwiecinska, S.; Kosek, M.; Jastrzebski, J.; Pregowski, J.; Kruk, M.; Rozanski, J.; et al. Computed tomography angiography for prediction of atrial fibrillation after coronary artery bypass grafting: Proof of concept. J. Cardiol. 2015, 65, 285-292. [CrossRef]

109. Shen, M.J.; Shinohara, T.; Park, H.-W.; Frick, K.; Ice, D.S.; Choi, E.-K.; Han, S.; Maruyama, M.; Sharma, R.; Shen, C.; et al. Continuous Low-Level Vagus Nerve Stimulation Reduces Stellate Ganglion Nerve Activity and Paroxysmal Atrial Tachyarrhythmias in Ambulatory Canines. Circulation 2011, 123, 2204-2212. [CrossRef]

110. Chen, P.-S.; Chen, L.S.; Fishbein, M.C.; Lin, S.F.; Nattel, S. Role of the autonomic nervous system in atrial fibrillation: Pathophysiology and therapy. Circ Res. 2014, 114, 1500-1515. [CrossRef]

111. Balcioğlu, A.S.; Çiçek, D.; Akinci, S.; Eldem, H.O.; Bal, U.A.; Okyay, K.; Muderrisoglu, I.H. Arrhythmogenic Evidence for Epicardial Adipose Tissue: Heart Rate Variability and Turbulence are Influenced by Epicardial Fat Thickness. Pacing Clin. Electrophysiol. 2015, 38, 99-106. [CrossRef] [PubMed]

112. Danik, S.; Neuzil, P.; D’Avila, A.; Malchano, Z.J.; Kralovec, S.; Ruskin, J.N.; Reddy, V. Evaluation of Catheter Ablation of Periatrial Ganglionic Plexi in Patients with Atrial Fibrillation. Am. J. Cardiol. 2008, 102, 578-583. [CrossRef] [PubMed]

113. Perez, M.V.; Wang, P.J.; Larson, J.C.; Virnig, B.A.; Cochrane, B.; Curb, J.D.; Klein, L.; Manson, J.E.; Martin, L.W.; Robinson, J.; et al. Effects of postmenopausal hormone therapy on incident atrial fibrillation: TheWomen's health initiative randomized controlled trials. Circ. Arrhythm. Electrophysiol. 2012, 5, 1108-1116. [CrossRef]

114. Bernasochi, G.B.; Boon, W.C.; Curl, C.L.; Varma, U.; Pepe, S.; Tare, M.; Parry, L.J.; Dimitriadis, E.; Harrap, S.B.; Nalliah, C.J.; et al. Pericardial adipose and aromatase: A new translational target for aging, obesity and arrhythmogenesis? J. Mol. Cell. Cardiol. 2017, 111, 96-101. [CrossRef]

115. Ernault, A.C.; Meijborg, V.M.F.; Coronel, R. Modulation of Cardiac Arrhythmogenesis by Epicardial Adipose Tissue: JACC State-of-the-Art Review. J. Am. Coll. Cardiol. 2021, 78, 1730-1745. [CrossRef] [PubMed]

116. Wong, C.X.; Sullivan, T.; Sun, M.T.; Mahajan, R.; Pathak, R.K.; Middeldorp, M.; Twomey, D.; Ganesan, A.N.; Rangnekar, G.; Roberts-Thomson, K.C.; et al. Obesity and the risk of incident, post-operative, and post-ablation atrial fibrillation: A metaanalysis of 626,603 individuals in 51 studies. JACC Clin. Electrophysiol. 2015, 1, 139-152. [CrossRef] [PubMed]

117. Thanassoulis, G.; Massaro, J.M.; O’Donnell, C.J.; Hoffmann, U.; Levy, D.; Ellinor, P.T.; Wang, T.J.; Schnabel, R.B.; Vasan, R.S.; Fox, C.S.; et al. Pericardial fat is associated with prevalent atrial fibrillation: The Framingham heart study. Circ. Arrhythm. Electrophysiol. 2010, 3, 345-350. [CrossRef] [PubMed]

118. Al Chekakie, M.O.; Welles, C.C.; Metoyer, R.; Ibrahim, A.; Shapira, A.R.; Cytron, J.; Santucci, P.; Wilber, D.J.; Akar, J.G. Pericardial fat is independently associated with human atrial fibrillation. J. Am. Coll. Cardiol. 2010, 56, 784-788. [CrossRef]

119. Batal, O.; Schoenhagen, P.; Shao, M.; Ayyad, A.E.; Van Wagoner, D.R.; Halliburton, S.S.; Tchou, P.J.; Chung, M.K. Left Atrial Epicardial Adiposity and Atrial Fibrillation. Circ. Arrhythmia Electrophysiol. 2010, 3, 230-236. [CrossRef]

120. Muhib, S.; Fujino, T.; Sato, N.; Hasebe, N. Epicardial Adipose Tissue Is Associated With Prevalent Atrial Fibrillation in Patients with Hypertrophic Cardiomyopathy. Int. Heart J. 2013, 54, 297-303. [CrossRef]

121. Wong, C.; Abed, H.S.; Molaee, P.; Nelson, A.; Brooks, A.G.; Sharma, G.; Leong, D.P.; Lau, D.H.; Middeldorp, M.; Roberts-Thomson, K.C.; et al. Pericardial Fat Is Associated with Atrial Fibrillation Severity and Ablation Outcome. J. Am. Coll. Cardiol. 2011, 57, 1745-1751. [CrossRef] [PubMed]

122. Tsao, H.-M.; Hu, W.-C.; Wu, M.-H.; Tai, C.-T.; Lin, Y.-J.; Chang, S.-L.; Lo, L.-W.; Hu, Y.-F.; Tuan, T.-C.; Wu, T.-J.; et al. Quantitative Analysis of Quantity and Distribution of Epicardial Adipose Tissue Surrounding the Left Atrium in Patients with Atrial Fibrillation and Effect of Recurrence after Ablation. Am. J. Cardiol. 2011, 107, 1498-1503. [CrossRef] [PubMed]

123. Wong, C.X.; Sun, M.T.; Odutayo, A.; Emdin, C.A.; Mahajan, R.; Lau, D.H.; Pathak, R.; Wong, D.T.; Selvanayagam, J.B.; Sanders, P.; et al. Associations of Epicardial, Abdominal, and Overall Adiposity with Atrial Fibrillation. Circ. Arrhythmia Electrophysiol. 2016, 9, e004378. [CrossRef] [PubMed]

124. Gaeta, M.; Bandera, F.; Tassinari, F.; Capasso, L.; Cargnelutti, M.; Pelissero, G.; Malavazos, A.E.; Ricci, C. Is epicardial fat depot associated with atrial fibrillation? A systematic review and meta-analysis. Europace 2017, 19, 747-752. [CrossRef]

125. Huang, C.; Wang, Y.; Li, X.; Ren, L.; Zhao, J.; Hu, Y.; Zhang, L.; Fan, G.; Xu, J.; Gu, X.; et al. Clinical features of patients infected with 2019 novel coronavirus in Wuhan, China. Lancet 2020, 395, 497-506. [CrossRef]

126. Feng, X.; Li, S.; Sun, Q.; Zhu, J.; Chen, B.; Xiong, M.; Cao, G. Immune-Inflammatory Parameters in COVID-19 Cases: A Systematic Review and Meta-Analysis. Front. Med. 2020, 7, 301. [CrossRef]

127. Gąsecka, A.; Filipiak, K.J.; Jaguszewski, M.J. Impaired microcirculation function in COVID-19 and implications for potential therapies. Cardiol. J. 2020, 27, 485-488.

128. Poggiali, E.; Zaino, D.; Immovilli, P.; Rovero, L.; Losi, G.; Dacrema, A.; Nuccetelli, M.; Vadacca, G.B.; Guidetti, D.; Vercelli, A.; et al. Lactate dehydrogenase and C-reactive protein as predictors of respiratory failure in COVID-19 patients. Clin. Chim. Acta 2020, 509, 135-138. [CrossRef]

129. Ruetzler, K.; Szarpak, Ł.; Ładny, J.R.; Gąsecka, A.; Gilis-Malinowska, N.; Pruc, M.; Smereka, J.; Nowak, B.; Filipiak, K.J.; Jaguszewski, M.J. D-dimer levels predict COVID-19 severity and mortality. Kardiol. Pol. 2021, 79, 217-218. [CrossRef] 
130. Szarpak, L.; Zaczynski, A.; Kosior, D.; Bialka, S.; Ladny, J.R.; Gilis-Malinowska, N.; Smereka, J.; Kanczuga-Koda, L.; Gasecka, A.; Filipiak, K.J.; et al. Evidence of diagnostic value of ferritin in patients with COVID-19. Cardiol. J. 2020, 27, 886-887. [CrossRef]

131. Rychter, A.M.; Zawada, A.; Ratajczak, A.E.; Dobrowolska, A.; Krela-Kaźmierczak, I. Should patients with obesity be more afraid of COVID-19? Obes. Rev. 2020, 21, 13083. [CrossRef] [PubMed]

132. Ryan, P.M.; Caplice, N.M. Is Adipose Tissue a Reservoir for Viral Spread, Immune Activation, and Cytokine Amplification in Coronavirus Disease 2019? Obesity 2020, 28, 1191-1194. [CrossRef] [PubMed]

133. Abrishami, A.; Eslami, V.; Baharvand, Z.; Khalili, N.; Saghamanesh, S.; Zarei, E.; Sanei-Taheri, M. Epicardial adipose tissue, inflammatory biomarkers and COVID-19: Is there a possible relationship? Int. Immunopharmacol. 2021, 90, 107174. [CrossRef]

134. Deng, M.; Qi, Y.; Deng, L.; Wang, H.; Xu, Y.; Li, Z.; Meng, Z.; Tang, J.; Dai, Z. Obesity as a Potential Predictor of Disease Severity in Young COVID-19 Patients: A Retrospective Study. Obesity 2020, 28, 1815-1825. [CrossRef] [PubMed]

135. Iacobellis, G.; Secchi, F.; Capitanio, G.; Basilico, S.; Schiaffino, S.; Boveri, S.; Sardanelli, F.; Romanelli, M.M.C.; Malavazos, A.E. Epicardial Fat Inflammation in Severe COVID-19. Obesity 2020, 28, 2260-2262. [CrossRef] [PubMed]

136. Grodecki, K.; Lin, A.; Razipour, A.; Cadet, S.; McElhinney, P.A.; Chan, C.; Pressman, B.D.; Julien, P.; Maurovich-Horvat, P.; Gaibazzi, N.; et al. Epicardial adipose tissue is associated with extent of pneumonia and adverse outcomes in patients with COVID-19. Metabolism 2021, 115, 154436. [CrossRef]

137. Wei, Z.; Geng, Y.; Huang, J.; Qian, H. Pathogenesis and management of myocardial injury in coronavirus disease 2019. Eur. J. Heart Fail. 2020, 22, 1994-2006. [CrossRef]

138. Geng, Y.-J.; Wei, Z.-Y.; Qian, H.-Y.; Huang, J.; Lodato, R.; Castriotta, R.J. Pathophysiological characteristics and therapeutic approaches for pulmonary injury and cardiovascular complications of coronavirus disease 2019. Cardiovasc. Pathol. 2020, 47, 107228. [CrossRef]

139. Gąsecka, A.; Borovac, J.A.; Guerreiro, R.A.; Giustozzi, M.; Parker, W.; Caldeira, D.; Chiva-Blanch, G. Thrombotic Complications in Patients with COVID-19: Pathophysiological Mechanisms, Diagnosis, and Treatment. Cardiovasc. Drugs Ther. 2021, 35, 215-229. [CrossRef]

140. Szarpak, L.; Filipiak, K.J.; Skwarek, A.; Pruc, M.; Rahnama, M.; Denegri, A.; Jachowicz, M.; Dawidowska, M.; Gasecka, A.; Jaguszewski, M.J.; et al. Outcomes and mortality associated with atrial arrhythmias among patients hospitalized with COVID-19: A systematic review and meta-analysis. Cardiol. J. 2021. [CrossRef]

141. Nucera, G.; Chirico, F.; Rafique, Z.; Gilis-Malinowska, N.; Gasecka, A.; Litvinova, N.; Wang, B.; Ilesanmi, O.; Pruc, M.; Jaguszewski, M.J.; et al. Need to update cardiological guidelines to prevent COVID-19 related myocardial infarction and ischemic stroke. Cardiol. J. 2021. [CrossRef] [PubMed]

142. Gasecka, A.; Pruc, M.; Kukula, K.; Gilis-Malinowska, N.; Filipiak, K.J.; Jaguszewski, M.J.; Szarpak, L. Post-COVID-19 heart syndrome. Cardiol. J. 2021, 28, 353-354. [CrossRef] [PubMed]

143. Hui, H.; Zhang, Y.; Yang, X.; Wang, X.; He, B.; Li, L.; Li, H.; Tian, J.; Chen, Y. Clinical and radiographic features of cardiac injury in patients with 2019 novel coronavirus pneumonia. MedRxiv 2020. [CrossRef]

144. Wei, Z.-Y.; Qiao, R.; Chen, J.; Huang, J.; Wang, W.-J.; Yu, H.; Xu, J.; Wu, H.; Wang, C.; Gu, C.-H.; et al. Pre-existing Health Conditions and Epicardial Adipose Tissue Volume: Potential Risk Factors for Myocardial Injury in COVID-19 Patients. Front. Cardiovasc. Med. 2021, 7, 585220. [CrossRef] [PubMed]

145. Launbo, N.; Zobel, E.H.; Von Scholten, B.J.; Færch, K.; Jørgensen, P.G.; Christensen, R.H. Targeting epicardial adipose tissue with exercise, diet, bariatric surgery or pharmaceutical interventions: A systematic review and meta-analysis. Obes. Rev. 2021, 22, 13136. [CrossRef]

146. Rabkin, S.W.; Campbell, H. Comparison of reducing epicardial fat by exercise, diet or bariatric surgery weight loss strategies: A systematic review and meta-analysis. Obes. Rev. 2015, 16, 406-415. [CrossRef]

147. Christensen, R.H.; Wedell-Neergaard, A.S.; Lehrskov, L.L.; Legaard, G.E.; Dorph, E.; Larsen, M.K.; Launbo, N.; Fagerlind, S.R.; Seide, S.K.; Nymand, S.; et al. Effect of Aerobic and Resistance Exercise on Cardiac Adipose Tissues: Secondary Analyses From a Randomized Clinical Trial. JAMA Cardiol. 2019, 4, 778-787. [CrossRef]

148. Fernandez-Del-Valle, M.; Gonzales, J.U.; Kloiber, S.; Mitra, S.; Klingensmith, J.; Larumbe-Zabala, E. Effects of resistance training on MRI-derived epicardial fat volume and arterial stiffness in women with obesity: A randomized pilot study. Eur. J. Appl. Physiol. 2018, 118, 1231-1240. [CrossRef]

149. Kahl, K.; Kerling, A.; Tegtbur, U.; Gützlaff, E.; Herrmann, J.; Borchert, L.; Ates, Z.; Westhoff-Bleck, M.; Hueper, K.; Hartung, D Effects of additional exercise training on epicardial, intra-abdominal and subcutaneous adipose tissue in major depressive disorder: A randomized pilot study. J. Affect. Disord. 2016, 192, 91-97. [CrossRef]

150. Fornieles González, G.; Rosety Rodríguez, M.A.; Pery Bohorquez, M.T.; Diaz Ordóñez, A.; Rosety Rodríguez, J.; Pery Bohorquez, M.T.; Brenes Martin, F.; Escribano Ocon, A.; Rosety Rodríguez, M.; Ordóñez Muñoz, F.J.; et al. A home-based treadmill training reduced epicardial and abdominal fat in postmenopausal women with metabolic syndrome. Nutr. Hosp. 2014, 30, 609-613. [CrossRef]

151. Konwerski, M.; Postuła, M.; Barczuk-Falęcka, M.; Czajkowska, A.; Mróz, A.; Witek, K.; Bakalarski, W.; Gąsecka, A.; Małek, Ł.; Mazurek, T. Epicardial Adipose Tissue and Cardiovascular Risk Assessment in Ultra-Marathon Runners: A Pilot Study. Int. J. Environ. Res. Public Health 2021, 18, 3136. [CrossRef]

152. Gepner, Y.; Shelef, I.; Schwarzfuchs, D.; Zelicha, H.; Tene, L.; Yaskolka Meir, A.; Tsaban, G.; Cohen, N.; Bril, N.; Rein, M.; et al Effect of distinct lifestyle interventions on mobilization of fat storage pools CENTRAL magnetic resonance imaging randomized controlled trial. Circulation 2018, 137, 1143-1157. [CrossRef] [PubMed] 
153. Kim, M.-K.; Tanaka, K.; Matuso, T.; Endo, T.; Tomita, T.; Maeda, S.; Ajisaka, R. Comparison of epicardial, abdominal and regional fat compartments in response to weight loss. Nutr. Metab. Cardiovasc. Dis. 2009, 19, 760-766. [CrossRef] [PubMed]

154. Snel, M.; Jonker, J.T.; Hammer, S.; Kerpershoek, G.; Lamb, H.J.; Meinders, A.E.; Pijl, H.; de Roos, A.; Romijn, J.A.; Smit, J.W.; et al. Long-Term Beneficial Effect of a 16-Week Very Low Calorie Diet on Pericardial Fat in Obese Type 2 Diabetes Mellitus Patients. Obesity 2012, 20, 1572-1576. [CrossRef] [PubMed]

155. Iacobellis, G.; Singh, N.; Wharton, S.; Sharma, A.M. Substantial Changes in Epicardial Fat Thickness after Weight Loss in Severely Obese Subjects. Obesity 2008, 16, 1693-1697. [CrossRef] [PubMed]

156. Willens, H.J.; Byers, P.; Chirinos, J.A.; Labrador, E.; Hare, J.M.; de Marchena, E. Effects of Weight Loss after Bariatric Surgery on Epicardial Fat Measured Using Echocardiography. Am. J. Cardiol. 2007, 99, 1242-1245. [CrossRef]

157. Gaborit, B.; Jacquier, A.; Kober, F.; Abdesselam, I.; Cuisset, T.; Boullu-Ciocca, S.; Emungania, O.; Alessi, M.C.; Clément, K.; Bernard, M.; et al. Effects of bariatric surgery on cardiac ectopic fat: Lesser decrease in epicardial fat compared to visceral fat loss and no change in myocardial triglyceride content. J. Am. Coll. Cardiol. 2012, 60, 1381-1389. [CrossRef]

158. Hannukainen, J.C.; Lautamäki, R.; Pärkkä, J.; Strandberg, M.; Saunavaara, V.; Hurme, S.; Soinio, M.; Dadson, P.; Virtanen, K.A.; Grönroos, T.; et al. Reversibility of myocardial metabolism and remodelling in morbidly obese patients 6 months after bariatric surgery. Diabetes Obes. Metab. 2018, 20,963-973. [CrossRef]

159. Graziani, F.; Leone, A.M.; Cialdella, P.; Basile, E.; Pennestrì, F.; Della Bona, R.; Iaconelli, A.; Liuzzo, G.; Biasucci, L.M.; Cardillo, M.T.; et al. Effects of bariatric surgery on cardiac remodeling: Clinical and pathophysiologic implications. Int. J. Cardiol. 2013, 168, 4277-4279. [CrossRef]

160. Alexopoulos, N.; Melek, B.H.; Arepalli, C.D.; Hartlage, G.R.; Chen, Z.; Kim, S.; Stillman, A.E.; Raggi, P. Effect of intensive versus moderate lipid-lowering therapy on epicardial adipose tissue in hyperlipidemic post-menopausal women: A substudy of the BELLES trial (beyond endorsed lipid lowering with EBT scanning). J. Am. Coll. Cardiol. 2013, 61, 1956-1961. [CrossRef]

161. Soucek, F.; Covassin, N.; Singh, P.; Ruzek, L.; Kara, T.; Suleiman, M.; Lerman, A.; Koestler, C.; Friedman, P.A.; Lopez-Jimenez, F.; et al. Effects of Atorvastatin $(80 \mathrm{mg})$ Therapy on Quantity of Epicardial Adipose Tissue in Patients Undergoing Pulmonary Vein Isolation for Atrial Fibrillation. Am. J. Cardiol. 2015, 116, 1443-1446. [CrossRef] [PubMed]

162. Parisi, V.; Petraglia, L.; D’Esposito, V.; Cabaro, S.; Rengo, G.; Caruso, A.; Grimaldi, M.G.; Baldascino, F.; De Bellis, A.; Vitale, D.; et al. Statin therapy modulates thickness and inflammatory profile of human epicardial adipose tissue. Int. J. Cardiol. 2019, 274, 326-330. [CrossRef] [PubMed]

163. Raggi, P.; Gadiyaram, V.; Zhang, C.; Chen, Z.; Lopaschuk, G.; Stillman, A.E. Statins Reduce Epicardial Adipose Tissue Attenuation Independent of Lipid Lowering: A Potential Pleiotropic Effect. J. Am. Heart Assoc. 2019, 8, e013104. [CrossRef] [PubMed]

164. Almeida, S.O.; Budoff, M. Effect of statins on atherosclerotic plaque. Trends Cardiovasc. Med. 2019, 29, 451-455. [CrossRef] [PubMed]

165. Tawakol, A.; Fayad, Z.A.; Mogg, R.; Alon, A.; Klimas, M.T.; Dansky, H.; Subramanian, S.S.; Abdelbaky, A.; Rudd, J.; Farkouh, M.E.; et al. Intensification of Statin Therapy Results in a Rapid Reduction in Atherosclerotic Inflammation: Results of a Multicenter Fluorodeoxyglucose-Positron Emission Tomography/Computed Tomography Feasibility Study. J. Am. Coll. Cardiol. 2013, 62, 909-917. [CrossRef]

166. Yang, Q.; Qi, X.; Dang, Y.; Li, Y.; Song, X.; Hao, X. Effects of atorvastatin on atrial remodeling in a rabbit model of atrial fibrillation produced by rapid atrial pacing. BMC Cardiovasc. Disord. 2016, 16, 142. [CrossRef] [PubMed]

167. Li, Y.; Tang, B.; Guo, F.; Li, J.; Han, W.; Tang, Q.; Zhang, Y. Effect of atorvastatin on left atrial function of patients with paroxysmal atrial fibrillation. Genet. Mol. Res. 2013, 12, 3488-3494. [CrossRef]

168. Fauchier, L.; Pierre, B.; de Labriolle, A.; Grimard, C.; Zannad, N.; Babuty, D. Antiarrhythmic Effect of Statin Therapy and Atrial Fibrillation: A Meta-Analysis of Randomized Controlled Trials. J. Am. Coll. Cardiol. 2008, 51, 828-835. [CrossRef]

169. Fang, W.; Li, H.-J.; Zhang, H.; Jiang, S. The role of statin therapy in the prevention of atrial fibrillation: A meta-analysis of randomized controlled trials. Br. J. Clin. Pharmacol. 2012, 74, 744-756. [CrossRef]

170. Liu, T.; Li, L.; Korantzopoulos, P.; Liu, E.; Li, G. Statin use and development of atrial fibrillation: A systematic review and meta-analysis of randomized clinical trials and observational studies. Int. J. Cardiol. 2008, 126, 160-170. [CrossRef]

171. Akahori, H.; Tsujino, T.; Naito, Y.; Matsumoto, M.; Sasaki, N.; Iwasaku, T.; Eguchi, A.; Sawada, H.; Hirotani, S.; Masuyama, T. Atorvastatin ameliorates cardiac fibrosis and improves left ventricular diastolic function in hypertensive diastolic heart failure model rats. J. Hypertens. 2014, 32, 1534-1541. [CrossRef] [PubMed]

172. Gómez-Garre, D.; González-Rubio, M.L.; Muñoz-Pacheco, P.; Caro-Vadillo, A.; Aragoncillo, P.; Fernández-Cruz, A. Rosuvastatin added to standard heart failure therapy improves cardiac remodelling in heart failure rats with preserved ejection fraction. Eur. $J$. Heart Fail. 2010, 12, 903-912. [CrossRef] [PubMed]

173. Beck, A.L.; Otto, M.E.; D'avila, L.B.; Netto, F.M.; Armendaris, M.K.; Sposito, A.C. Diastolic function parameters are improved by the addition of simvastatin to enalapril-based treatment in hypertensive individuals. Atherosclerosis 2012, 222, 444-448. [CrossRef] [PubMed]

174. Okura, H.; Asawa, K.; Kubo, T.; Taguchi, H.; Toda, I.; Yoshiyama, M.; Yoshikawa, J.; Yoshida, K. Impact of Statin Therapy on Systemic Inflammation, Left Ventricular Systolic and Diastolic Function and Prognosis in Low Risk Ischemic Heart Disease Patients without History of Congestive Heart Failure. Intern. Med. 2007, 46, 1337-1343. [CrossRef] [PubMed] 
175. Preiss, D.; Campbell, R.T.; Murray, H.M.; Ford, I.; Packard, C.J.; Sattar, N.; Rahimi, K.; Colhoun, H.M.; Waters, D.D.; LaRosa, J.C.; et al. The effect of statin therapy on heart failure events: A collaborative meta-analysis of unpublished data from major randomized trials. Eur. Heart J. 2015, 36, 1536-1546. [CrossRef]

176. Marume, K.; Takashio, S.; Nagai, T.; Tsujita, K.; Saito, Y.; Yoshikawa, T.; Anzai, T. Effect of Statins on Mortality in Heart Failure with Preserved Ejection Fraction without Coronary Artery Disease-Report from the JASPER Study. Circ. J. 2019, 83, 357-367. [CrossRef] [PubMed]

177. Lee, M.-S.; Duan, L.; Clare, R.; Hekimian, A.; Spencer, H.; Chen, W. Comparison of Effects of Statin Use on Mortality in Patients with Heart Failure and Preserved versus Reduced Left Ventricular Ejection Fraction. Am. J. Cardiol. 2018, 122, 405-412. [CrossRef]

178. Liu, G.; Zheng, X.X.; Xu, Y.L.; Ru, J.; Hui, R.T.; Huang, X.H. Meta-analysis of the effect of statins on mortality in patients with preserved ejection fraction. Am. J. Cardiol. 2014, 113, 1198-1204. [CrossRef] [PubMed]

179. Fukuta, H.; Goto, T.; Wakami, K.; Ohte, N. The effect of statins on mortality in heart failure with preserved ejection fraction: A meta-analysis of propensity score analyses. Int. J. Cardiol. 2016, 214, 301-306. [CrossRef]

180. Tavazzi, L.; Maggioni, A.P.; Marchioli, R.; Barlera, S.; Franzosi, M.G.; Latini, R.; Lucci, D.; Nicolosi, G.L.; Porcu, M.; Tognoni, G.; et al. Effect of rosuvastatin in patients with chronic heart failure (the GISSIHF trial): A randomised, double-blind, placebo-controlled trial. Lancet 2008, 372, 1231-1239. [CrossRef]

181. Rivas Galvez, R.E.; Morales Portano, J.D.; Trujillo Cortes, R.; Gomez Alvarez, E.B.; Sanchez Cubias, S.M.; Zelaya, S.M. Reduction of epicardial adipose tissue thickness with PCSK9 inhibitors. Eur. Heart J. 2020, 41 (Suppl. 2), ehaa946-3008. [CrossRef]

182. Zinman, B.; Wanner, C.; Lachin, J.M.; Fitchett, D.; Bluhmki, E.; Hantel, S.; Mattheus, M.; Devins, T.; Johansen, O.E.; Woerle, H.J.; et al. Empagliflozin, Cardiovascular Outcomes, and Mortality in Type 2 Diabetes. N. Engl. J. Med. 2015, 373, 2117-2128. [CrossRef]

183. Marso, S.P.; Daniels, G.H.; Brown-Frandsen, K.; Kristensen, P.; Mann, J.F.E.; Nauck, M.A.; Nissen, S.E.; Pocock, S.; Poulter, N.R.; Ravn, L.S.; et al. Liraglutide and Cardiovascular Outcomes in Type 2 Diabetes. N. Engl. J. Med. 2016, 375, 311-322. [CrossRef] [PubMed]

184. Kernan, W.N.; Viscoli, C.M.; Furie, K.L.; Young, L.H.; Inzucchi, S.E.; Gorman, M.; Guarino, P.D.; Lovejoy, A.M.; Peduzzi, P.N.; Conwit, R.; et al. Pioglitazone after Ischemic Stroke or Transient Ischemic Attack. New Engl. J. Med. 2016, 374, 1321-1331. [CrossRef]

185. Mohan, M.; Al-Talabany, S.; McKinnie, A.; Mordi, I.R.; Singh, J.; Gandy, S.J.; Baig, F.; Hussain, M.S.; Bhalraam, U.; Khan, F.; et al. A randomized controlled trial of metformin on left ventricular hypertrophy in patients with coronary artery disease without diabetes: The MET-REMODEL trial. Eur. Heart J. 2019, 40, 3409-3417. [CrossRef] [PubMed]

186. Zhou, J.; Massey, S.; Story, D.; Li, L. Metformin: An Old Drug with New Applications. Int. J. Mol. Sci. 2018, 19, 2863. [CrossRef]

187. Jing, Y.; Wu, F.; Li, D.; Yang, L.; Li, Q.; Li, R. Metformin improves obesity-associated inflammation by altering macrophages polarization. Mol. Cell. Endocrinol. 2018, 461, 256-264. [CrossRef]

188. Salvatore, T.; Pafundi, P.C.; Morgillo, F.; Di Liello, R.; Galiero, R.; Nevola, R.; Marfella, R.; Monaco, L.; Rinaldi, L.; Adinolfi, L.E.; et al. Metformin: An old drug against old age and associated morbidities. Diabetes Res. Clin. Pr. 2020, 160, 108025. [CrossRef]

189. Morgillo, F.; Fasano, M.; Della Corte, C.M.; Sasso, F.C.; Papaccio, F.; Viscardi, G.; Esposito, G.; Di Liello, R.; Normanno, N.; Capuano, A.; et al. Results of the safety run-in part of the METAL (METformin in Advanced Lung cancer) study: A multicentre, open-label phase I-II study of metformin with erlotinib in second-line therapy of patients with stage IV non-small-cell lung cancer. ESMO Open 2017, 2, e000132. [CrossRef]

190. Spencer, M.; Yang, L.; Adu, A.; Finlin, B.S.; Zhu, B.; Shipp, L.R.; Rasouli, N.; Peterson, C.A.; Kern, P.A. Pioglitazone Treatment Reduces Adipose Tissue Inflammation through Reduction of Mast Cell and Macrophage Number and by Improving Vascularity. PLoS ONE 2014, 9, e102190. [CrossRef]

191. Xie, X.; Sinha, S.; Yi, Z.; Langlais, P.R.; Madan, M.; Bowen, B.P.; Willis, W.; Meyer, C. Role of adipocyte mitochondria in inflammation, lipemia and insulin sensitivity in humans: Effects of pioglitazone treatment. Int. J. Obes. 2018, 42, 213-220. [CrossRef] [PubMed]

192. Cameron, A.R.; Morrison, V.; Levin, D.; Mohan, M.; Forteath, C.; Beall, C.; McNeilly, A.; Balfour, D.J.; Savinko, T.; Wong, A.K.; et al. Anti-Inflammatory Effects of Metformin Irrespective of Diabetes Status. Circ. Res. 2016, 119, 652-665. [CrossRef] [PubMed]

193. Ziyrek, M.; Kahraman, S.; Ozdemir, E.; Dogan, A. Metformin monotherapy significantly decreases epicardial adipose tissue thickness in newly diagnosed type 2 diabetes patients. Rev Port. Cardiol. 2019, 38, 419-423. [CrossRef] [PubMed]

194. Tokubuchi, I.; Tajiri, Y.; Iwata, S.; Hara, K.; Wada, N.; Hashinaga, T.; Nakayama, H.; Mifune, H.; Yamada, K. Beneficial effects of metformin on energy metabolism and visceral fat volume through a possible mechanism of fatty acid oxidation in human subjects and rats. PLoS ONE 2017, 12, e0171293. [CrossRef]

195. Ding, Y.; Zhou, Y.; Ling, P.; Feng, X.; Luo, S.; Zheng, X.; Little, P.J.; Xu, S.; Weng, J. Metformin in cardiovascular diabetology: A focused review of its impact on endothelial function. Theranostics 2021, 11, 9376-9396. [CrossRef] [PubMed]

196. Chen, W.J.; Greulich, S.; van der Meer, R.W.; Rijzewijk, L.J.; Lamb, H.J.; de Roos, A.; Smit, J.W.; Romijn, J.A.; Ruige, J.B.; Lammertsma, A.A.; et al. Activin a is associated with impaired myocardial glucose metabolism and left ventricular remodeling in patients with uncomplicated type 2 diabetes. Cardiovasc. Diabetol. 2013, 12, 150. [CrossRef] 
197. Sardu, C.; D’Onofrio, N.; Torella, M.; Portoghese, M.; Loreni, F.; Mureddu, S.; Signoriello, G.; Scisciola, L.; Barbieri, M.; Rizzo, M.R.; et al. Pericoronary fat inflammation and Major Adverse Cardiac Events (MACE) in prediabetic patients with acute myocardial infarction: Effects of metformin. Cardiovasc. Diabetol. 2019, 18, 1-11. [CrossRef]

198. Varjabedian, L.; Bourji, M.; Pourafkari, L.; Nader, N.D. Cardioprotection by Metformin: Beneficial Effects Beyond Glucose Reduction. Am. J. Cardiovasc. Drugs 2018, 18, 181-193. [CrossRef]

199. Triposkiadis, F.; Xanthopoulos, A.; Parissis, J.; Butler, J.; Farmakis, D. Pathogenesis of chronic heart failure: Cardiovascular aging, risk factors, comorbidities, and disease modifiers. Hear. Fail. Rev. 2020, 27, 337-344. [CrossRef]

200. Sag, D.; Carling, D.; Stout, R.D.; Suttles, J. Adenosine 5'-Monophosphate-Activated Protein Kinase Promotes Macrophage Polarization to an Anti-Inflammatory Functional Phenotype. J. Immunol. 2008, 181, 8633-8641. [CrossRef]

201. Xu, L.; Nagata, N.; Nagashimada, M.; Zhuge, F.; Ni, Y.; Chen, G.; Mayoux, E.; Kaneko, S.; Ota, T. SGLT2 Inhibition by Empagliflozin Promotes Fat Utilization and Browning and Attenuates Inflammation and Insulin Resistance by Polarizing M2 Macrophages in Diet-induced Obese Mice. EBioMedicine 2017, 20, 137-149. [CrossRef] [PubMed]

202. Lee, Y.-S.; Park, M.-S.; Choung, J.-S.; Kim, S.-S.; Oh, H.-H.; Choi, C.-S.; Ha, S.-Y.; Kang, Y.; Kim, Y.; Jun, H.-S. Glucagon-like peptide-1 inhibits adipose tissue macrophage infiltration and inflammation in an obese mouse model of diabetes. Diabetologia 2012, 55, 2456-2468. [CrossRef]

203. Salim, H.M.; Fukuda, D.; Higashikuni, Y.; Tanaka, K.; Hirata, Y.; Yagi, S.; Soeki, T.; Shimabukuro, M.; Sata, M. Teneligliptin, a dipeptidyl peptidase- 4 inhibitor, attenuated pro-inflammatory phenotype of perivascular adipose tissue and inhibited atherogenesis in normoglycemic apolipoprotein-E-deficient mice. Vasc. Pharmacol. 2017, 96-98, 19-25. [CrossRef] [PubMed]

204. Grosso, A.F.; de Oliveira, S.F.; Higuchi Mde, L.; Favarato, D.; Dallan, L.A.; da Luz, P.L. Synergistic antiinflammatory effect: Simvastatin and pioglitazone reduce inflammatory markers of plasma and epicardial adipose tissue of coronary patients with metabolic syndrome. Diabetol. Metab. Syndr. 2014, 6, 47. [CrossRef]

205. Sacks, H.S.; Fain, J.N.; Cheema, P.; Bahouth, S.W.; Garrett, E.; Wolf, R.Y.; Wolford, D.; Samaha, J. Inflammatory genes in epicardial fat contiguous with coronary atherosclerosis in the metabolic syndrome and type 2 diabetes: Changes associated with pioglitazone. Diabetes Care 2011, 34, 730-733. [CrossRef]

206. Distel, E.; Penot, G.; Cadoudal, T.; Balguy, I.; Durant, S.; Benelli, C. Early induction of a brown-like phenotype by rosiglitazone in the epicardial adipose tissue of fatty Zucker rats. Biochimie 2012, 94, 1660-1667. [CrossRef]

207. Dormandy, J.A.; Charbonnel, B.; Eckland, D.J.A.; Erdmann, E.; Massi-Benedetti, M.; Moules, I.K.; Skene, A.M.; Tan, M.H.; Lefèbvre, P.J.; Murray, G.D.; et al. Secondary prevention of macrovascular events in patients with type 2 diabetes in the PROactive Study (PROspective pioglitAzone Clinical Trial In macroVascular Events): A randomised controlled trial. Lancet 2005, 366, 1279-1289. [CrossRef]

208. Lincoff, A.M.; Wolski, K.; Nicholls, S.J.; Nissen, S.E. Pioglitazone and risk of cardiovascular events in patients with type 2 diabetes mellitus: A metaanalysis of randomized trials. JAMA 2007, 298, 1180-1188. [CrossRef]

209. Bouchi, R.; Terashima, M.; Sasahara, Y.; Asakawa, M.; Fukuda, T.; Takeuchi, T.; Nakano, Y.; Murakami, M.; Minami, I.; Izumiyama, H.; et al. Luseogliflozin reduces epicardial fat accumulation in patients with type 2 diabetes: A pilot study. Cardiovasc. Diabetol. 2017, 16, 1-9. [CrossRef]

210. Fukuda, T.; Bouchi, R.; Terashima, M.; Sasahara, Y.; Asakawa, M.; Takeuchi, T.; Nakano, Y.; Murakami, M.; Minami, I.; Izumiyama, H.; et al. Ipragliflozin Reduces Epicardial Fat Accumulation in Non-Obese Type 2 Diabetic Patients with Visceral Obesity: A Pilot Study. Diabetes Ther. 2017, 8, 851-861. [CrossRef] [PubMed]

211. Sato, T.; Aizawa, Y.; Yuasa, S.; Fujita, S.; Ikeda, Y.; Okabe, M. The Effect of Dapagliflozin Treatment on Epicardial Adipose Tissue Volume and P-Wave Indices: An Ad-hoc Analysis of the Previous Randomized Clinical Trial. J. Atheroscler. Thromb. 2020, 27, 1348-1358. [CrossRef] [PubMed]

212. Correale, M.; Lamacchia, O.; Ciccarelli, M.; Dattilo, G.; Tricarico, L.; Brunetti, N.D. Vascular and metabolic effects of SGLT2i and GLP-1 in heart failure patients. Heart Fail. Rev. 2021, 1-12. [CrossRef] [PubMed]

213. Zhou, Z.; Jardine, M.J.; Li, Q.; Neuen, B.L.; Cannon, C.P.; de Zeeuw, D.; Edwards, R.; Levin, A.; Mahaffey, K.W.; Perkovic, V.; et al Effect of SGLT2 Inhibitors on Stroke and Atrial Fibrillation in Diabetic Kidney Disease: Results from the CREDENCE Trial and Meta-Analysis. Stroke 2021, 52, 1545-1556. [CrossRef]

214. Bolinder, J.; Ljunggren, Ö.; Kullberg, J.; Johansson, L.; Wilding, J.; Langkilde, A.M.; Sugg, J.; Parikh, S. Effects of Dapagliflozin on Body Weight, Total Fat Mass, and Regional Adipose Tissue Distribution in Patients with Type 2 Diabetes Mellitus with Inadequate Glycemic Control on Metformin. J. Clin. Endocrinol. Metab. 2012, 97, 1020-1031. [CrossRef] [PubMed]

215. Iacobellis, G.; Gra-Menendez, S. Effects of Dapagliflozin on Epicardial Fat Thickness in Patients with Type 2 Diabetes and Obesity. Obesity 2020, 28, 1068-1074. [CrossRef] [PubMed]

216. Díaz-Rodríguez, E.; Agra, R.M.; Fernández, A.L.; Adrio, B.; García-Caballero, T.; Juanatey, J.R.G.; Eiras, S. Effects of dapagliflozin on human epicardial adipose tissue: Modulation of insulin resistance, inflammatory chemokine production, and differentiation ability. Cardiovasc. Res. 2018, 114, 336-346. [CrossRef]

217. Masson, W.; Lavalle-Cobo, A.; Nogueira, J.P. Effect of SGLT2-Inhibitors on Epicardial Adipose Tissue: A Meta-Analysis. Cells 2021, 10, 2150. [CrossRef]

218. Iacobellis, G.; Mohseni, M.; Bianco, S.; Banga, P.K. Liraglutide causes large and rapid epicardial fat reduction. Obesity 2017, 25, 311-316. [CrossRef] 
219. Dutour, A.; Abdesselam, I.; Ancel, P.; Kober, F.; Mrad, G.; Darmon, P.; Ronsin, O.; Pradel, V.; Lesavre, N.; Martin, J.C.; et al. Exenatide decreases liver fat content and epicardial adipose tissue in patients with obesity and type 2 diabetes: A prospective randomized clinical trial using magnetic resonance imaging and spectroscopy. Diabetes Obes. Metab. 2016, 18, 882-891. [CrossRef]

220. Pastel, E.; McCulloch, L.J.; Ward, R.; Joshi, S.; Gooding, K.M.; Shore, A.C.; Kos, K. GLP-1 analogue-induced weight loss does not improve obesity-induced AT dysfunction. Clin. Sci. 2017, 131, 343-353. [CrossRef]

221. Al-Barazanji, K.A.; Arch, J.R.; Buckingham, R.E.; Tadayyon, M. Central exendin-4 infusion reduces body weight without altering plasma leptin in (fa/fa) Zucker rats. Obes. Res. 2000, 8, 317-323. [CrossRef] [PubMed]

222. Rakipovski, G.; Rolin, B.; Nøhr, J.; Klewe, I.; Frederiksen, K.S.; Augustin, R.; Hecksher-Sørensen, J.; Ingvorsen, C.; Polex-Wolf, J.; Knudsen, L.B. The GLP-1 Analogs Liraglutide and Semaglutide Reduce Atherosclerosis in ApoE-/- and LDLr-/- Mice by a Mechanism That Includes Inflammatory Pathways. JACC Basic Transl. Sci. 2018, 3, 844-857. [CrossRef]

223. Iacobellis, G.; Camarena, V.; Sant, D.W.; Wang, G. Human Epicardial Fat Expresses Glucagon-Like Peptide 1 and 2 Receptors Genes. Horm. Metab. Res. 2017, 49, 625-630. [CrossRef] [PubMed]

224. Yang, J.; Ren, J.; Song, J.; Liu, F.; Wu, C.; Wang, X.; Gong, L.; Li, W.; Xiao, F.; Yan, F.; et al. Glucagon-like peptide 1 regulates adipogenesis in 3T3-L1 preadipocytes. Int. J. Mol. Med. 2013, 31, 1429-1435. [CrossRef] [PubMed]

225. Beiroa, D.; Imbernon, M.; Gallego, R.; Senra, A.; Herranz, D.; Villarroya, F.; Serrano, M.; Fernø, J.; Salvador, J.; Escalada, J.; et al. GLP-1 Agonism Stimulates Brown Adipose Tissue Thermogenesis and Browning through Hypothalamic AMPK. Diabetes 2014, 63, 3346-3358. [CrossRef]

226. Lima-Martínez, M.M.; Paoli, M.; Rodney, M.; Balladares, N.; Contreras, M.; D’Marco, L.; Iacobellis, G. Effect of sitagliptin on epicardial fat thickness in subjects with type 2 diabetes and obesity: A pilot study. Endocrine 2015, 51, 448-455. [CrossRef]

227. Packer, M. Have dipeptidyl peptidase-4 inhibitors ameliorated the vascular complications of type 2 diabetes in large-scale trials? The potential confounding effect of stem-cell chemokines. Cardiovasc. Diabetol. 2018, 17, 9. [CrossRef]

228. Peng, H.; Zhang, H.; Zhu, H. Blocking CXCR7-mediated adipose tissue macrophages chemotaxis attenuates insulin resistance and inflammation in obesity. Biochem. Biophys. Res. Commun. 2016, 479, 649-655. [CrossRef]

229. Mulvihill, E.E.; Varin, E.M.; Ussher, J.R.; Campbell, J.E.; Bang, K.A.; Abdullah, T.; Baggio, L.L.; Drucker, D.J. Inhibition of Dipeptidyl Peptidase-4 Impairs Ventricular Function and Promotes Cardiac Fibrosis in High Fat-Fed Diabetic Mice. Diabetes 2015, 65, 742-754. [CrossRef]

230. Aroor, A.; McKarns, S.; Nistala, R.; Demarco, V.; Gardner, M.; Garcia-Touza, M.; Whaley-Connell, A.; Sowers, J.R. DPP-4 Inhibitors as Therapeutic Modulators of Immune Cell Function and Associated Cardiovascular and Renal Insulin Resistance in Obesity and Diabetes. Cardiorenal Med. 2013, 3, 48-56. [CrossRef]

231. Shah, Z.; Kampfrath, T.; Deiuliis, J.; Zhong, J.; Pineda, C.; Ying, Z.; Xu, X.; Lu, B.; Moffatt-Bruce, S.; Durairaj, R.; et al. LongTerm Dipeptidyl-Peptidase 4 Inhibition Reduces Atherosclerosis and Inflammation via Effects on Monocyte Recruitment and Chemotaxis. Circulation 2011, 124, 2338-2349. [CrossRef]

232. Tomović, K.; Lazarevic, J.; Kocić, G.; Deljanin-Ilic, M.; Anderluh, M.; Smelcerovic, A. Mechanisms and pathways of antiinflammatory activity of DPP-4 inhibitors in cardiovascular and renal protection. Med. Res. Rev. 2019, 39, 404-422. [CrossRef] [PubMed]

233. Sakata, K.; Hayakawa, M.; Yano, Y.; Tamaki, N.; Yokota, N.; Eto, T.; Watanabe, R.; Hirayama, N.; Matsuo, T.; Kuroki, K.; et al. Efficacy of alogliptin, a dipeptidyl peptidase-4 inhibitor, on glucose parameters, the activity of the advanced glycation end product (AGE) - receptor for AGE (RAGE) axis and albuminuria in Japanese type 2 diabetes. Diabetes/Metabolism Res. Rev. 2013, 29, 624-630. [CrossRef] [PubMed]

234. Sato, N.; Nakamura, Y.; Yamadera, S.; Inagaki, M.; Kenmotsu, S.; Saito, H.; Oguchi, T.; Tsuji, M.; Hirokazu, C.; Ohsawa, I.; et al. Linagliptin Inhibits Lipopolysaccharide-Induced Inflammation Concentration-Dependently And -Independently. J. Inflamm. Res. 2019, ume 12, 285-291. [CrossRef]

235. Ishibashi, Y.; Matsui, T.; Maeda, S.; Higashimoto, Y.; Yamagishi, S.-I. Advanced glycation end products evoke endothelial cell damage by stimulating soluble dipeptidyl peptidase-4 production and its interaction with mannose 6-phosphate/insulin-like growth factor II receptor. Cardiovasc. Diabetologia 2013, 12, 125. [CrossRef]

236. Ridker, P.M.; Everett, B.M.; Thuren, T.; MacFadyen, J.G.; Chang, W.H.; Ballantyne, C.; Fonseca, F.; Nicolau, J.; Koenig, W.; Anker, S.D.; et al. Antiinflammatory Therapy with Canakinumab for Atherosclerotic Disease. N. Engl. J. Med. 2017, 377, 1119-1131. [CrossRef] [PubMed]

237. Ridker, P.M.; MacFadyen, J.G.; Everett, B.M.; Libby, P.; Thuren, T.; Glynn, R.J.; Kastelein, J.; Koenig, W.; Genest, J.; Lorenzatti, A.; et al. Relationship of C-reactive protein reduction to cardiovascular event reduction following treatment with canakinumab: A secondary analysis from the CANTOS randomised controlled trial. Lancet 2018, 391, 319-328. [CrossRef]

238. Cutolo, M.; Sulli, A.; Pizzorni, C.; Seriolo, B.; Straub, R.H. Anti-inflammatory mechanisms of methotrexate in rheumatoid arthritis. Ann. Rheum. Dis. 2001, 60, 729-735. [CrossRef]

239. Micha, R.; Imamura, F.; von Ballmoos, M.W.; Solomon, D.H.; Hernán, M.; Ridker, P.M.; Mozaffarian, D. Systematic Review and Meta-Analysis of Methotrexate Use and Risk of Cardiovascular Disease. Am. J. Cardiol. 2011, 108, 1362-1370. [CrossRef]

240. Ridker, P.M.; Everett, B.M.; Pradhan, A.; MacFadyen, J.G.; Solomon, D.H.; Zaharris, E.; Mam, V.; Hasan, A.; Rosenberg, Y.; Iturriaga, E.; et al. Low-Dose Methotrexate for the Prevention of Atherosclerotic Events. N. Engl. J. Med. 2019, 380, 752-762. [CrossRef] 
241. Nidorf, S.M.; Eikelboom, J.; Budgeon, C.A.; Thompson, P.L. Low-Dose Colchicine for Secondary Prevention of Cardiovascular Disease. J. Am. Coll. Cardiol. 2013, 61, 404-410. [CrossRef] [PubMed]

242. Nidorf, S.M.; Fiolet, A.T.L.; Mosterd, A.; Eikelboom, J.W.; Schut, A.; Opstal, T.S.J.; The, S.H.K.; Xu, X.-F.; Ireland, M.A.; Lenderink, T.; et al. Colchicine in Patients with Chronic Coronary Disease. N. Engl. J. Med. 2020, 383, 1838-1847. [CrossRef] [PubMed]

243. Tardif, J.-C.; Kouz, S.; Waters, D.D.; Bertrand, O.F.; Diaz, R.; Maggioni, A.P.; Pinto, F.J.; Ibrahim, R.; Gamra, H.; Kiwan, G.S.; et al. Efficacy and Safety of Low-Dose Colchicine after Myocardial Infarction. N. Engl. J. Med. 2019, 381, 2497-2505. [CrossRef] [PubMed] 